\title{
$\frac{28}{16}-4-79$

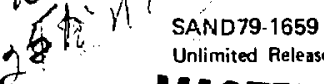 \\ Unlimited Release. \\ MASTE
}

\section{$\lambda$-3, Sandia's 100-J HF Laser System}

Flaymond A. Klein

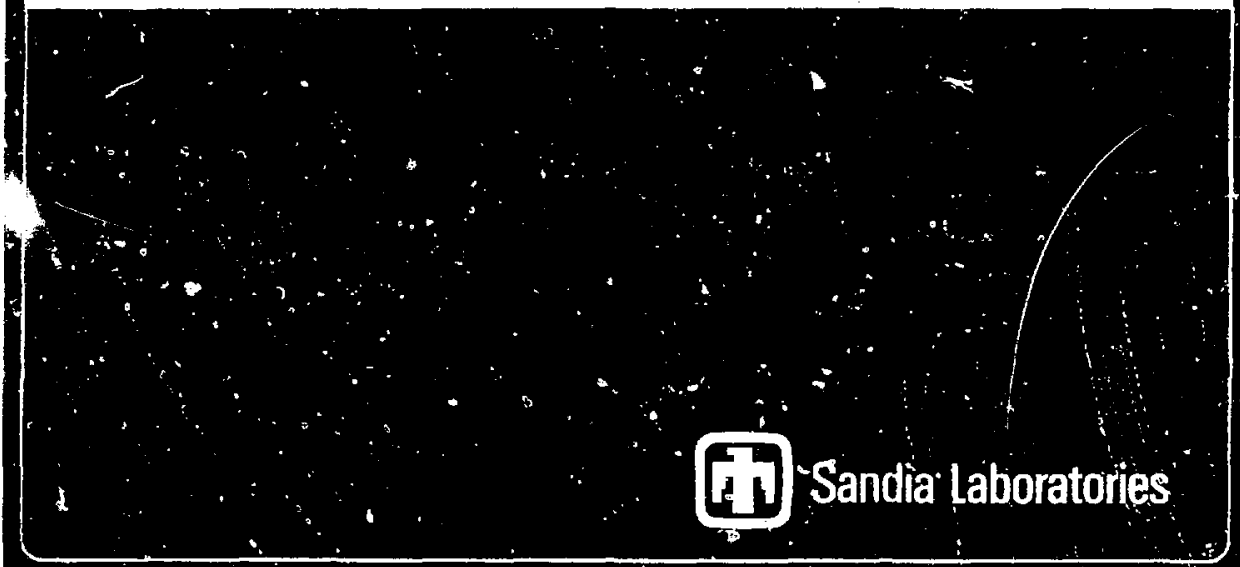

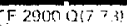


SAND79-1659

Unlimited Release

Printed Septenber 1979

h-3, SANDIA'S 100-J HF EASER SYSTE-

Raymond $A$. Klein

Laser Physics Research bivision 4212

Sandia Laboratories

Albuquerque, New Meyico 87185

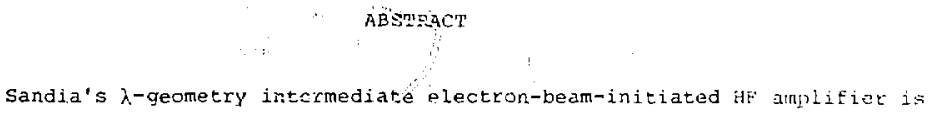

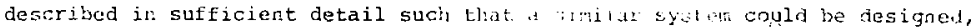
constructed and charactexized. Items included are the design of the laser cell, magnetic field design and measurenents, electron-beam calorimetry, and typical laser results. 


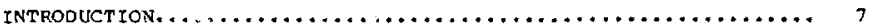

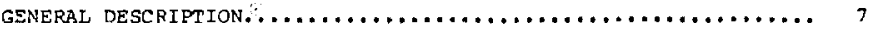

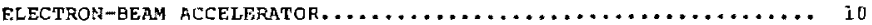

DESIGN ANU CONSTRICTION OF THE LASER CELL................ 13

DESCRIPTION OF THE MAGNETIC FIELD COILS................. 16

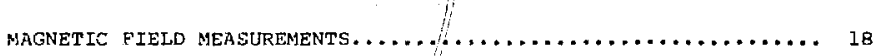

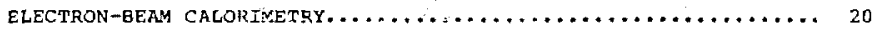

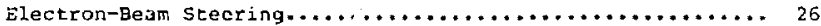

Electron-Beam Deposition....................... 27

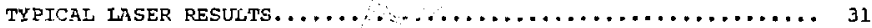

FIGURE CAPTIONS

Eigure 1. Schematic of the $i-3$ laser system..............

Figure 2. Fhotograph of $h-3$ l.ser sjstem............... 11

Figure 3. Photograph and schematic drawing of the

PI Model $110 n$ Marx generator................. i2

Figure 4. Electron-beam accelerator outgut savgiorms........ I4

Figure 5. Construction details of the center solenoid used to generate the guiding magnetic field..............

Figure 6. Construstion details of the beam deflection and electronmbeam turning coils.................. 19

Figure 7. Magnetic field current and time rate of change wE: the mangetic field as a function of time........ 21

Figure 8. Magnetic field measurements as a function of distance along the laser cell................ 22 
Figure 9. Geometry of the segmented 31 element

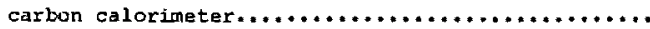

Figure 10. Radial electron-beam profiles and total transmitted energy as a function of optical magnetic field....

Figure 11. Electron-beam energy profiles at various distances and at two different gas pressures.............

Figure 12. Electron-bean energy transmitted at various locations and different ing $_{2}$ equivalent pressures....

Figure 13. Neasured electron-beam energy loss and calculated beam deposition as a function of density-length product.............................. 32

Figure 14. $\lambda-3 \mathrm{HF}$ laser oscillator characteristics.........

Drawing Captions

Drawing 1. Cell Adapter........................... 37

Drawing 2. Drift Section........................... 38

Drawing 2A. Drift Section Modification.................. 39

Drawing 3. cathode Tip............................ 40

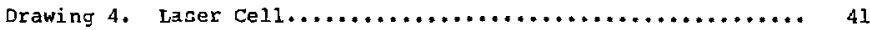

Drawing 5. Laser Cell subassemblies................... 42

Drawing 6 , Brewster Angle Window grolder................. 43

Drawing $7.15^{\circ}$ window Holder........................ 44

Drawing 8. Window clamp............................. 45 


\section{INTRODUCTION}

The $\lambda$-geometry HF laser $(\lambda-3)$ was developed to be used as an intermediate amplifier to drive Sandia's Phoenix I final amplificr. In the i-geometry, electrons produced in the accelerator are magnetically gnided into the laser cell at an angle which provides an unobstructed optical axis. This geometry, originally developed by E. L. natterson and R. A. Gerber at Sandia Laboratories, has been used to axially excite both $\mathrm{HF}^{1-3}$ and other gas lasers. ${ }^{4-6}$ The present laser, is iritiated by an intense electron beam from a Physics International ${ }^{7}$ Pulserad $110 \mathrm{~A}$ accelerator. This laser system ope:- tes with a gas mixture of $\mathrm{H}_{2}, \mathrm{~F}_{2}$ and $\mathrm{O}_{2}$ and produces laser energies in excess of $100 \mathrm{~J}$ in the wavelength region between 2.6 and 3.5 um.

The purpose of this report is to describe the laser system in sufficient detail such that a similar laser systent could be designed, constructed and characterized. One of the motivations for preparing this report was a suggestion from the Office of Inertial Fusion of the Department of Energy that this information be made available to incustry. Items that will be covered in this report are: a general description of the system, tine electron-bean accelerator together with modificacions, the cissign and construction of the laser cell, design of the angnetic field coils, magnetic field measurements, electron-beam calorimetry including beam steering and deposition, and, finally, some typical laser output results. Al.though this system was designed with the hF laser in mind, it can be used to produce many gas lasers requiring electron-bean initiation.

\section{GENERAL DESCRIPTION}

A schematic drawing of the laser system is shown in Fig. 1 . Not shown in the figure is the vacuum and gas handiing systems. They are described 
- RRE WSTEF ANGLE WINDOWS

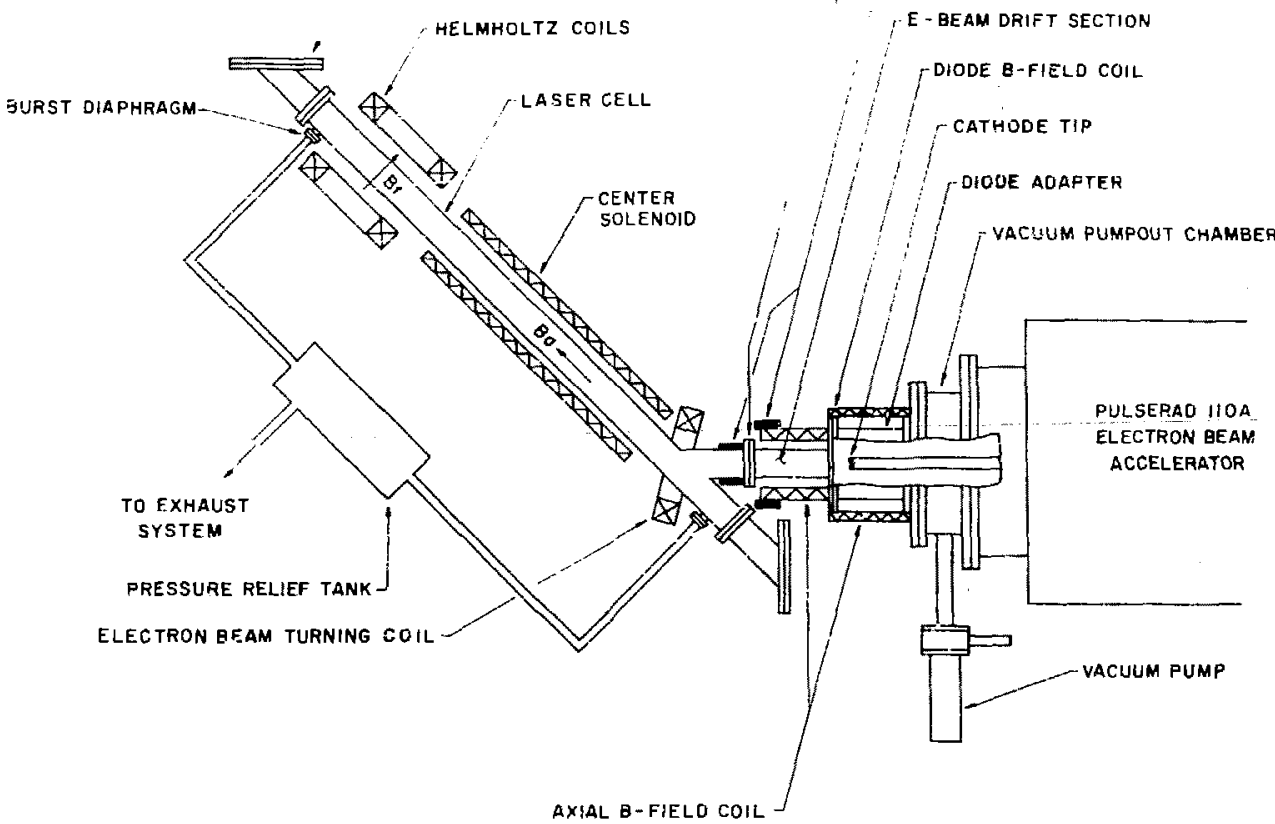

Figure 1. Schematic of the $\$-3$ laser syster. 
in detail in a recent sandia niemorandum. The peak electron energy is 1.2 Mev with a beam current of $35 \mathrm{kA}$ and a pulse width of $20 \mathrm{nsec}$ (FWHM). The electron-heam machine is capable of delivering approximately ann $\mathrm{J}$ at the anode foil. The machine has a diode extension which a? lows the diode to be immersed in a guiding magnetic field. The electrons, produced by a cold cathode, paiss through a $0.076-\mathrm{mm}$ thick-titaniun anode foil into the drift section. "The drift section is used to extend the laser cell away from the inachine to facilitate placement of the windows and optics. There is a $0.076-m$ m-thick stainless-steel foil between the drift section ano the lasor cell. This foil separates the gas in the laser cell from the gas in the drift section which is normally air at a.pressure of 1.75 Torr, which provides good electron-beam transport to the laser cell.

The electron beam is guided along the $6.35 \mathrm{~cm}-$ diameter staniess steel laser cell by the axial B-field coils shown in Fig. $l_{0}$ B-field smoothing coils are added in two locations to compensate for the effects of mounting flanges. An electron-beam turning coil is used to turn the electron bearn from the drift sectior into the lasex cell. To prevent aamage to the windrow at the end of the laser cell, the remaining electrons are deflected inte the cell wall by a pair of magnetic coils.

The laser cell, shown in Fig. 1 , has an active medium length of $91.4 \mathrm{ct}$ and an active volume of 2.9 liters, where the active volume is taken to be the region initiated by the electron beam. The total length of the cell is $148 \mathrm{~cm}$. The laser cell can be fitted with either Brewster angle windows (siown in Fig. 1) or windows with a wedge angle of $15^{\circ}$. Burst diaghragms which rupture during the latter part of the chemical reaction discharge the gases into a pressure relief tank to reduce the total pressure 
and tius prevent the laser cell from rupturing. The gases $\left(\mathrm{F}_{2}, \mathrm{H}_{2}, \mathrm{O}_{2}\right)$ reguired for the operation of the HF laser are nixed in the cell just prior to firing the electron-beam machine. The fluorine is added first, Eollowec by oxygen. Finally, the hydrogen is turbulently injected to Facilitate mixing. Normally the ratio of $E_{2}: \mathrm{O}_{2}: \mathrm{H}_{2}$ is $\mathrm{l}: 0.3: 0.25$ at total pressures less than 2 atmospheres. A photograph of the $1-3$ laser systen is shown in Fig. 2.

\section{ËECTRON-BEAM ACCEIJERATOR}

The electron-beam accelerator is a commercial device; therefore, only a brief description will be given of its operation. The modifications to the accelerator wili be given in somewhat more detail.

Basical.ly, the Pulserad systern consists of five subassemblies: the de power supply, the trigger amplifier, the Marx generator, the coaxial-B? unlein pulse forming line and the electron accelerator diode. The operation is as follows: Eirst the Marx generator is charged to the iesired level by the dc power supply. When charged, the system is triggered by a East-rising trigger pulse and begins to charge the alumlein. After appruximately 0.25 isec, the Blumlein reaches peak charge, at which time the output switch and prepulse switch close and the charge is transferred to tht diode. This particular machine has the low jitter option which gives an overali jitter of about lo nsec. A photograph of tive Marx generator and a schematic of its assembly are shown in Fig. 3 . Fhe diode was modified to accept the laser cell and to permit easy anode foil changes. The laser celi adapter shown in Dwg. 1 (drawings are locates at the end of this report) replaces the anode holder supplied with the rachire. The anode is a $0.0 \% 5-m m-t h i c k$ titanium foil and is held is position between the laser cell adapter and the laser cell 

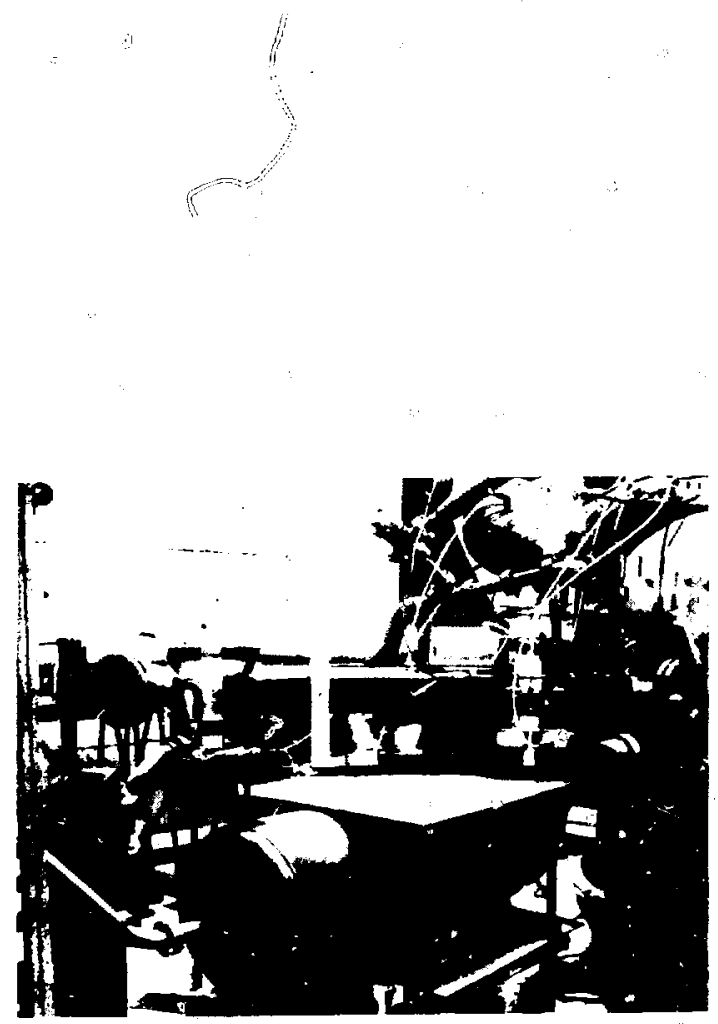

Figure 2. Fhutograpt of -3 laser system. 


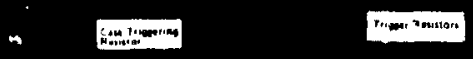

somen 0 an
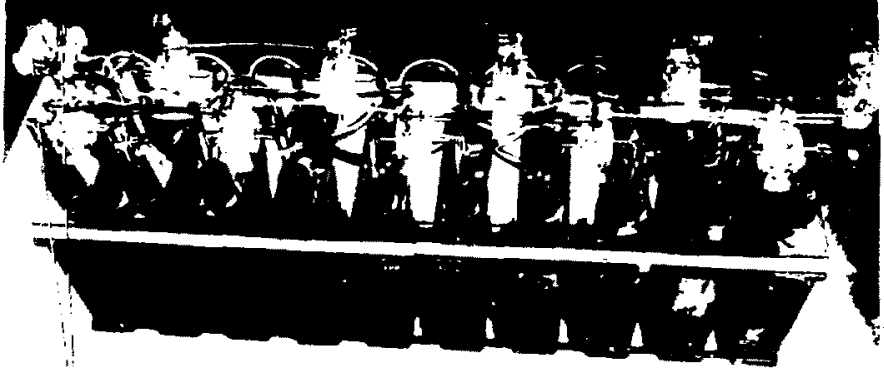

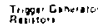

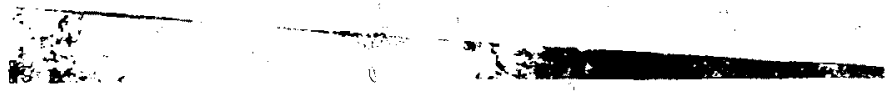

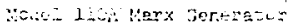

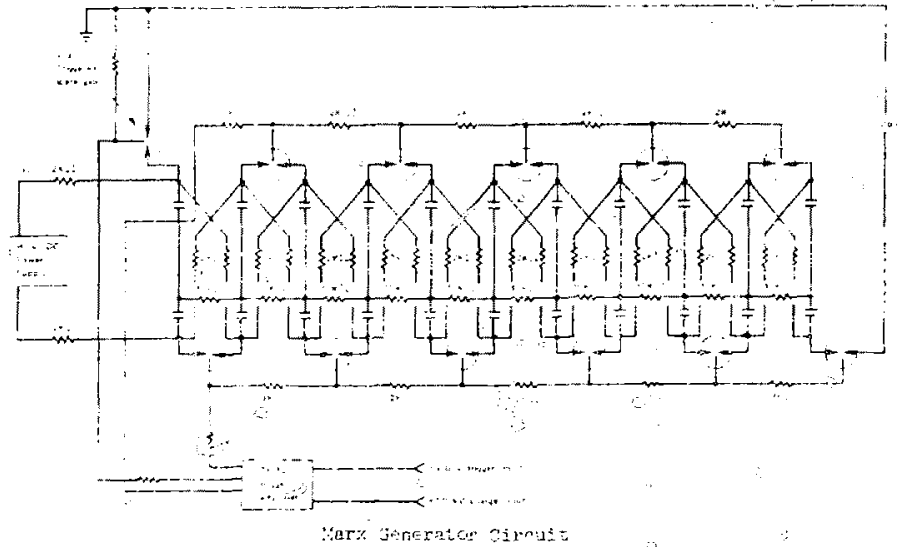

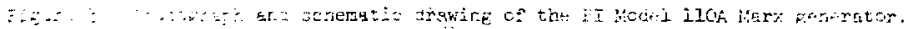


drift section shown in Dwg. 2 .

The cathode tip shown in sug, 3 replaces the cathode tip supplied $\therefore$

with the electron-herin machine. The anode-cathode spacing $1.51 .77 \mathrm{6m}$. $\because$

Typica: Marx generator output voltege, diode voltage and diode murrani traces after the machine fires are shown in Fiq. 4. For a chisks vo?tat? of + and $-50 \mathrm{kV}$, the peak Marx voltage is 1.02 av and the peak dinge roltage and current were $1.2 \mathrm{HV}$ and $39.1 \mathrm{kA}$, respertively.

DESIGN AND CONSTRUCTION OF THE IASER CELL

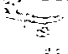
管

The first requirement on the laser cell was that it be long enour so trat a significant portion os thre election-bean

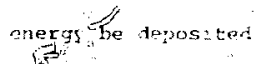
at the highest operating pressurs. "The range (an) for 1.2 MeV eiectrion in fluorine is approximately $0.66 \mathrm{~g} / \mathrm{cm}^{2} .9$ At a oressure of 2 atm, tise density $(C)$ of $\mathrm{F}_{2}$ is $0 / 0035 \mathrm{~g} / \mathrm{cm}^{3}$ yielding i length, (l), of $1.9 \mathrm{~m}$. Because of foil losses, scattering of electrins to the wall, and the observation that the effective linear range is only about 708 uf the tabulated range, the beam path in the cell was made $2.2 \mathrm{~m}$ Iong.

The secondtrequirement on the cell was thet it should allow the (1) applied magnetic field to diffuse through the wall in a time period Thort compared to the quarter-period of the magnetic field circuit ard yet be strong enough thithstand the reaction pressures. Field penetration requirements dictate that the cell wall nust be thin with respect to the skin depth. The penetration depth is given approximately by ${ }^{10} \delta=(-\mathrm{f} \mu \sigma)^{-1 / 2}$, where $E$ is the frequency of the magnetic Eiela, $u \leqslant$, is the permeability and $\checkmark$ is"the; conductivit; of the cell wall. It is ciear that the cell should be made out of a material with a low electrical conductivity. It is also important that the capacitor bank current have as long a period as possible. In kris particular case, the cell

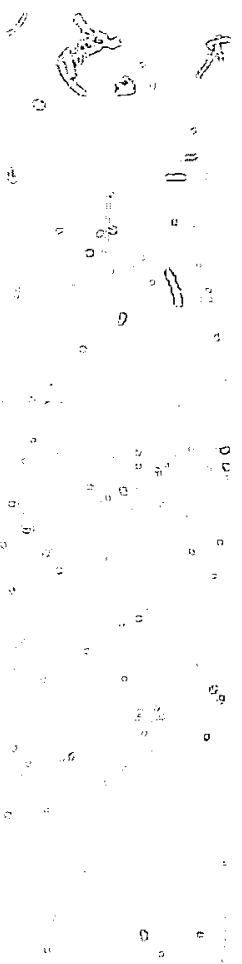


$\ldots$

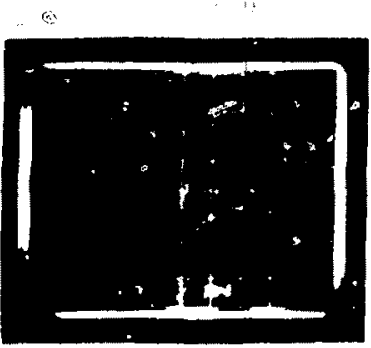

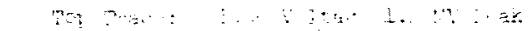

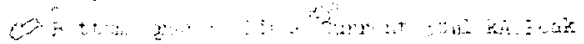

is

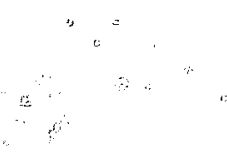

$\therefore$

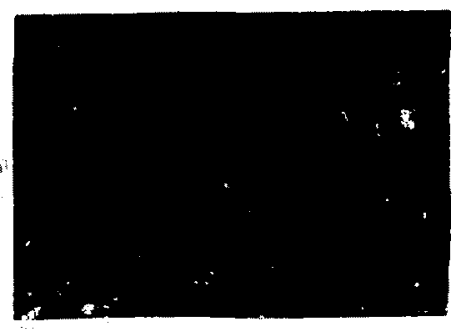

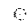

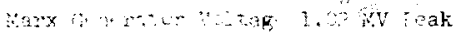

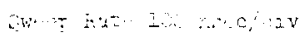
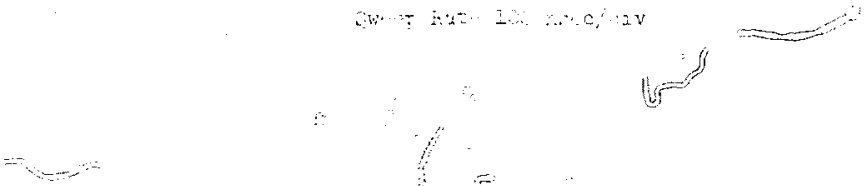

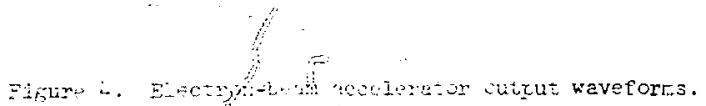


is made from stainless steel which has a conductivity of $1.1 \times 10^{6}$ mlis/m. and the magnetic field has a ruarter-period of $\approx 1.2 \mathrm{msec}$ or an frequency of $208 \mathrm{~Hz}$. When these valies aŕe substituted into the formula, one finds a penetration depth of $1.7 \mathrm{~cm}$. The cell was made of turirg wit: a wall thickness of approxinately $1.27 \mathrm{~mm}$ which gives a ratio of siin depth to thickness of about 10. Besides the wall thickness, care must also be taken, such that the magnetic field will diffuse, through the flanges. The Elanges are also made of stainless steel and were made as small in diameter as possible $(10.16 \mathrm{~cm})$ and as thin as possible $(0.54 \mathrm{cr})$...As will be described, whenever the B-fieid was decreaseri because of the thickness of the metal, B-field smoothing wils (Fis. 1) wer:- added to increase the interior magnetic field at these locarions. A detailed drawing of the cell is shown in subassembly B, Dwg. 4. The" gas feed lines are as small as possible to allow the magnetic field to diffuse through them. All components and flanges on the cell must be next to the cell to allow the magnetic field coils to slip over the cell. In all the experiments to date, only tre single section has been used.

Drawing 5 shows details of the various flanges on the laser cell. The flanges for the pressure relief diaphragms, shown in detail $z$, were made so that a V-gruoved clamp and a ingle bolt can be used to lucid the flanges together and allows ravid changing of the diagphragms betweer each laser shot. Captive o-tings were usea for ease of assemily. Drawings 6 and 7 show the design of th? window holders for the lasir. One at Brewster angle for sapphire and the other at a wedge angle of $15^{\circ}$. In both cases the o-ring grooves were made such that windows from $14 \mathrm{~cm}$ to $17.78 \mathrm{~cm}$ in dianeter couid be used. The window clamp is shown in Dwg. 8 . 


\section{OESCRIFTIOH OF THE MAGNETIC FIFLO COILS}

When trying to control an electron beam with a riayntic field it ia desiraile to have the applied magnetic field strength about equal to that of the self ragnetic field of the electron beam. This is just a rough estinate since propagation of che electron beam depends on bean curtent and electron voltage as well as gas concentration and pressure. sny design should have the flexibility to exceed this value by at least a Eactor of two. Only detailed electronmbean propagation studies will allow the determination of the optimum magnetic field conditions. An app:oximation for the self field at the edyes of a cylindricai eiectron beam is given by $B_{e-b e a n} \triangleq b_{j} I / 2 r$, where $r$ is the bean radius ill meters and $I$ is the total beam current in amperes. In this particular case, $==0.013 \mathrm{~m}, I=38.1 \mathrm{kn}$, so $\mathrm{B}_{\mathrm{e} \text {-beam }} \approx 0.59 \mathrm{~T}$ or $5.9 \mathrm{kG}$.

The coils shown in Fig. 1 axa all connected in series, therefore, the current through each cois is the same. The magnetic field calculaced ir each of these coils is such that the nagnetic fields on axis and in che cencer of each coil are equal. The magneric field is given by $B_{z}=\Lambda_{0} I(N / \ell)_{-} l+(2 R / L)^{2 ?-1 / 2}$, where $N / \ell$ is the number of turns per meter, $\bar{i}$ : is the length of the solenoid and $F$ is the radius. The conscruction of the center solenaid is shown in Fig. 5. In this case $L \gg 2 \mathrm{~F}$ so $\mathrm{B}_{\mathrm{z}} \equiv \mathrm{L}_{\mathrm{O}} \mathrm{I}(\mathrm{N} / \hat{L})$. This $91.4 \mathrm{~cm}$ long coil existed in our laborators so that the rest of the coils (diode coil, drift section coils, turning coils and beam deflection coils) were designed to match the magnetic Field of the center zolunoid. The diode coil and drift section coil are not shown but are similar to that shown in Fig. 5. The smoothing coils, constructed after the initial magnetic fiel.d measurements, provided the recessary additional field at various locations. The construction of 


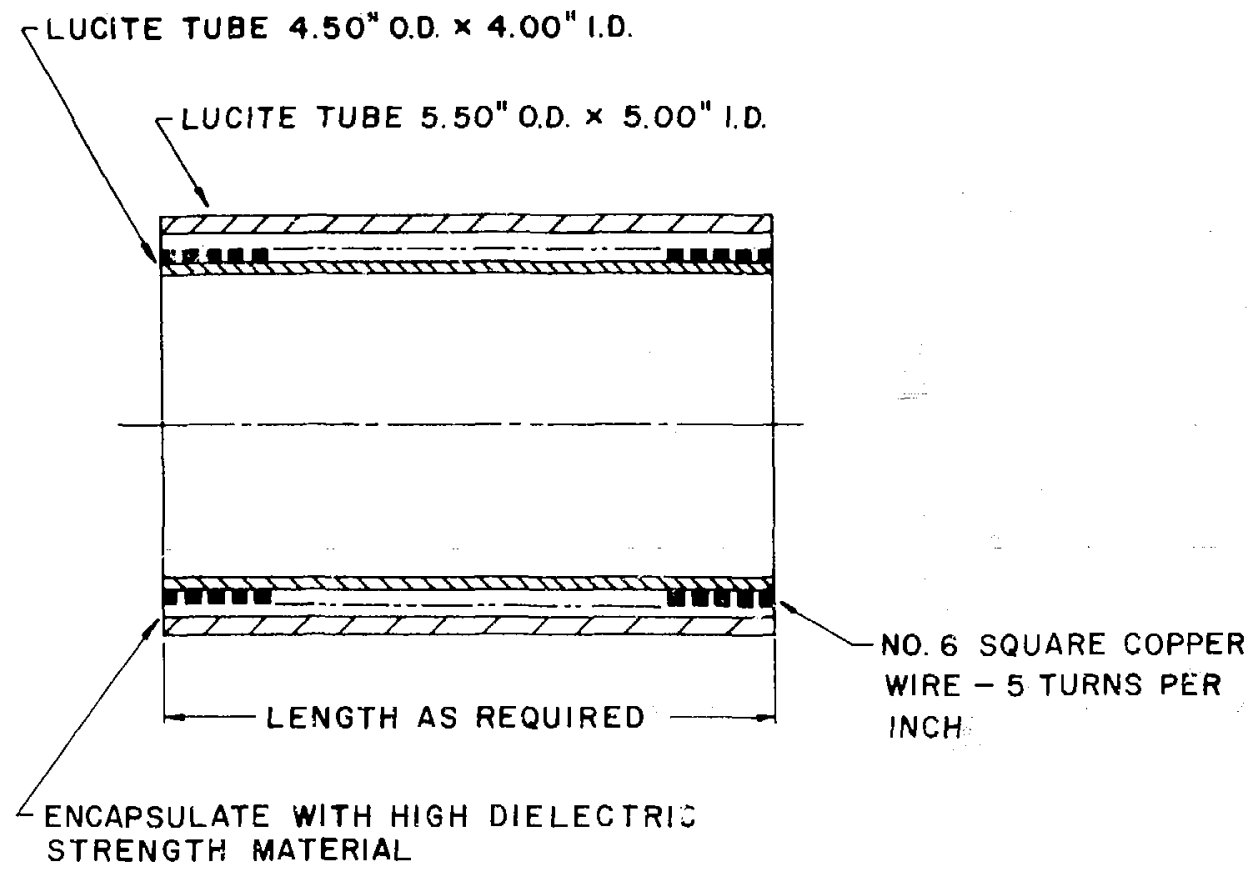

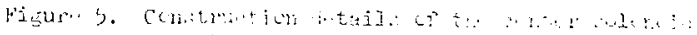

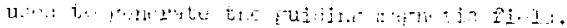


the beam deflection coils and the electron-beam turning coil is shown in Fig. 6. The diameter of these coils was chosen so that the electron-bearn turiling coil would fit over the junction where the el, wtron bean enters the cell, as shown in Fig. 1 .

Trie $91.4 \mathrm{cr}$ long solenoid is held in position by $5.0 \mathrm{~cm}$ Lucite clamps at each end ario mounted to a phenolic base. This base has a series of 1/4-irch-diameter screws so that the laser cell can be aligned with the electron-beam machine. Styrofoam inserts, at each end of the solemoid, are used to wenter the laser cell in the solenoid. Tre turning esil is helf in position wich two gimbalec clamps mounted on the laser cell Elange that connects to the draft section. This allows the coil to be moved in the horizontal direction and with adjustable screws so it can be tilted in the vertical direction.

MAGNETIC FIERD MEASUREMENTS

The current is supplied to the magnetic field coils by a comercially available capacitor bank. 11 The total capacity of this bank is $250 \mu f d s$ The charge voltage is variable from 1 to $20 \mathrm{kV}$. The total inductance of that magnetic Field coils connected in series is $2.24 \times 10^{-3} \mathrm{~h}$ giving a totai period of the current of $4.8 \mathrm{msec}$ or a quarter-period of $1.2 \mathrm{msec}$. The magnetic field can be varied fron $800 \mathrm{G}$ (charge voltage of $1 \mathrm{kv}$, $I=320 \mathrm{~A}$ ) to $16 \mathrm{kG}$ (charge voltage of $20 \mathrm{kV}, I=6.4 \mathrm{kA}$ ).

The magnetic field inside the cell was measured as a function of distaıce to determine uniformity. A dB/dt probe having a cross sectional area of $0.71 \mathrm{~cm}^{2}$ was used to infer the magnetic field values. The probe was made by wrapping 40 tirns of $\# 29$ copper wire on a 0.95 -cm-diameter core. The bank current was also monitored by measuring the voltage with a low inductance resistor whose value is $2.5 \mathrm{~m} \Omega$. After normalization, the 


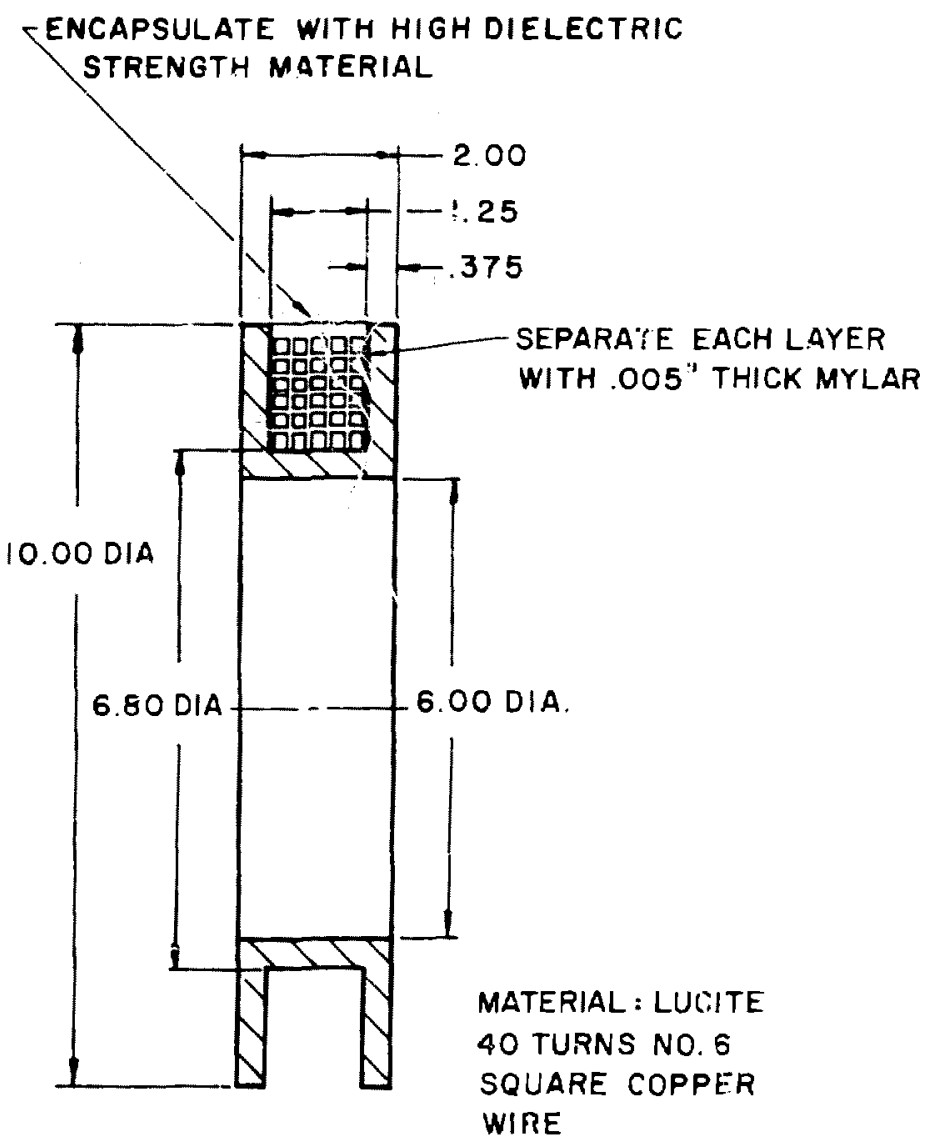

Figure 6. Construction aetails of the beam deflection ancicetron-bean turning coils. 
current could be used to monitor the magnetic field on the axis of the long solenoid. For the magnetic fiel's measurements, the bank was charged to a voltage of $1 \mathrm{kV}$. Typical capacitor bank current $a_{2} d \mathrm{~dB} / \mathrm{dt}$ traces are shown in Fig. 7. The magnetic field was determined by integrating the $\mathrm{dB} / \mathrm{dt}$ curve to the time of peak current, since the electron beam normally was fired at the time of peak current.

The magnetic field as a function of distance is shown in Fig. 8 . At tha location at which the beam entered the cell, the magnetic field probe was positioned such that only the magnetic field in the direction of the beam travel was measured. The magnetic field, shown in Fig. 8 , is $750 \mathrm{G}$ to within about \pm 298 . A few points near the $45^{\circ}$ bend were somewhat higher than this value. The points at distances less tinan 0 (anode position) were obtained by removiny the cathode and the cathode shank. These data were taken to ensure there was sufficient magnetic field in the diode. RLECTRON-BFAM CALORIMETRY

Electron-jeam calorinetry is important in the $\lambda$-geometry for $t$ reasons. First, the correct position of the turning coil can be determined to maximize beam propagation around the corner into the laser cell, and, secondly, it permits an estimate of the amount. of energy deposited in the gas as a function of distance and gas pressure by measuring the transmitted energy at various distances and pressures.

The calorimeter designed for this experiment is shown in Fig. 9. This 31 element, totally stopping, segmented carbon calorimeter facilitates the measurement of the radial energy distribution and transmitted energy. The calorimeter has an outside diameter of $5.72 \mathrm{~cm}$ with an element thickness of $0.64 \mathrm{~cm}$. The calorimeter was designed to 


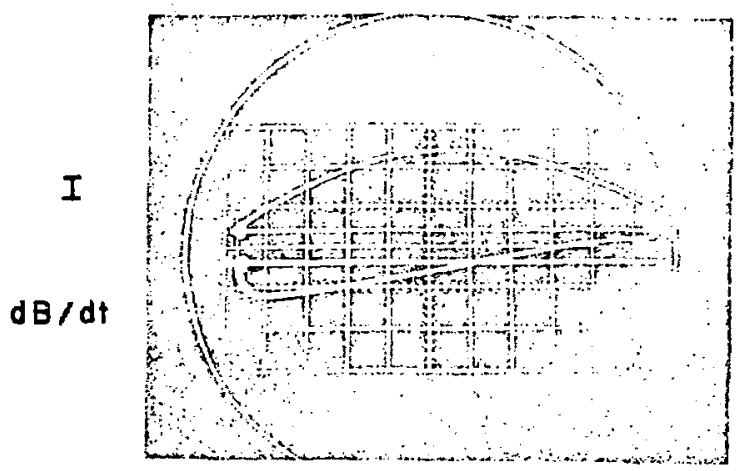

SWEEP RATE : $0.2 \mathrm{msec} / \mathrm{dIV}$

Figure 7. Magnetic field current and time rate of change
of the ragnetic iele as a function of tims. 


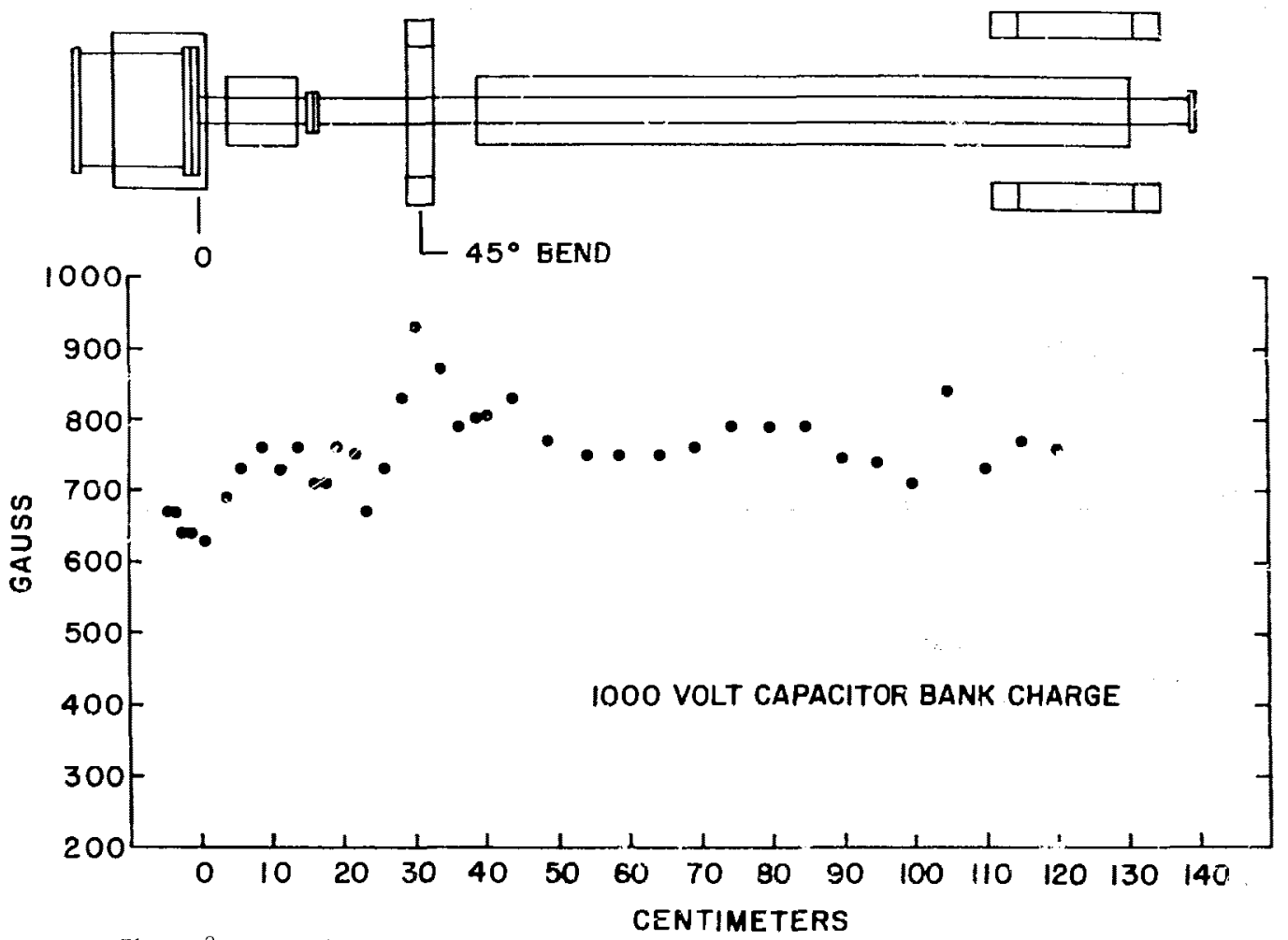

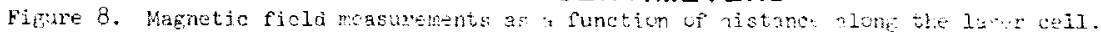




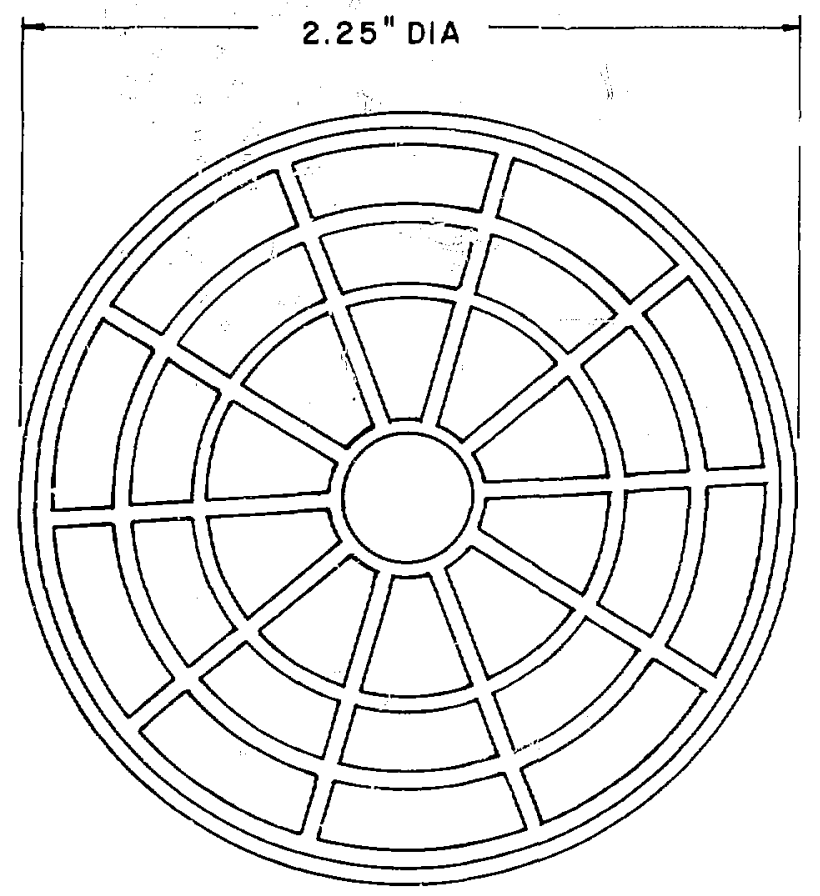

3) ELEMENT CALORIMETER

Figure 9. Georetry of the scemented 31 element carion zalorineter. 
provide good magnetic field penetration. The calorimeter voltage output versus deposited electron energy depends on the volume of the individual elenents, density of the material and the type of thermocouple used. In this case, all the elements have a volume of $0.37 \mathrm{~cm}^{3}$. The thermocouples are made of chromel-constantai? andare glued to a pumice base to reduce heat loss. The calibration of each eiement is $0.0956 \mathrm{mV} / \mathrm{J}$. This Sandia designed calorineter is now commercially available. 12

The output voltage from each thermocouple (normally 1 to $10 \mathrm{mV}$ ) is recorded with one of Sandia's calorimeter systems ${ }^{13}$ with a bank of strip-chart recorders. In some instances, after beam steering experiments were completed, some elements at the same radius were connected in series so that four chart recorders were used to measure transmitted electron-beam energy, as a function of radius.

A Iirst set of experiments were done to determine the effect of varying the magnetic field. These measurements were done at a distance of $16.5 \mathrm{~cm}$ from the anode, which is at the far end of the electron-beam drift section (see Figs. 1 and 8). For these measurements the pressure in tile drift section was normally 1.75 Torr of air. Figure 10 shows the radial electron-beam profiles at magnetic fields of $2,4,6$, and $8 \mathrm{~kg}$. The data points (except for the element in the center) were averages of the individual elements at the same radius. The number in parenthesis on each curve is the total energy measured and was obtained by adding the energy from each individual element. Figure 10 shows that for low magnetic fields ( 2 and $4 \mathrm{kG}$ ), the profile remains nearly constant and the applied field does not really alter the profile. At 6 and $8 \mathrm{~kg}$, the toansmitted energies are approximately equal and are about 108 higher than the low fieid conditions. The profile at $8 \mathrm{kG}$ shows a depression in the center 


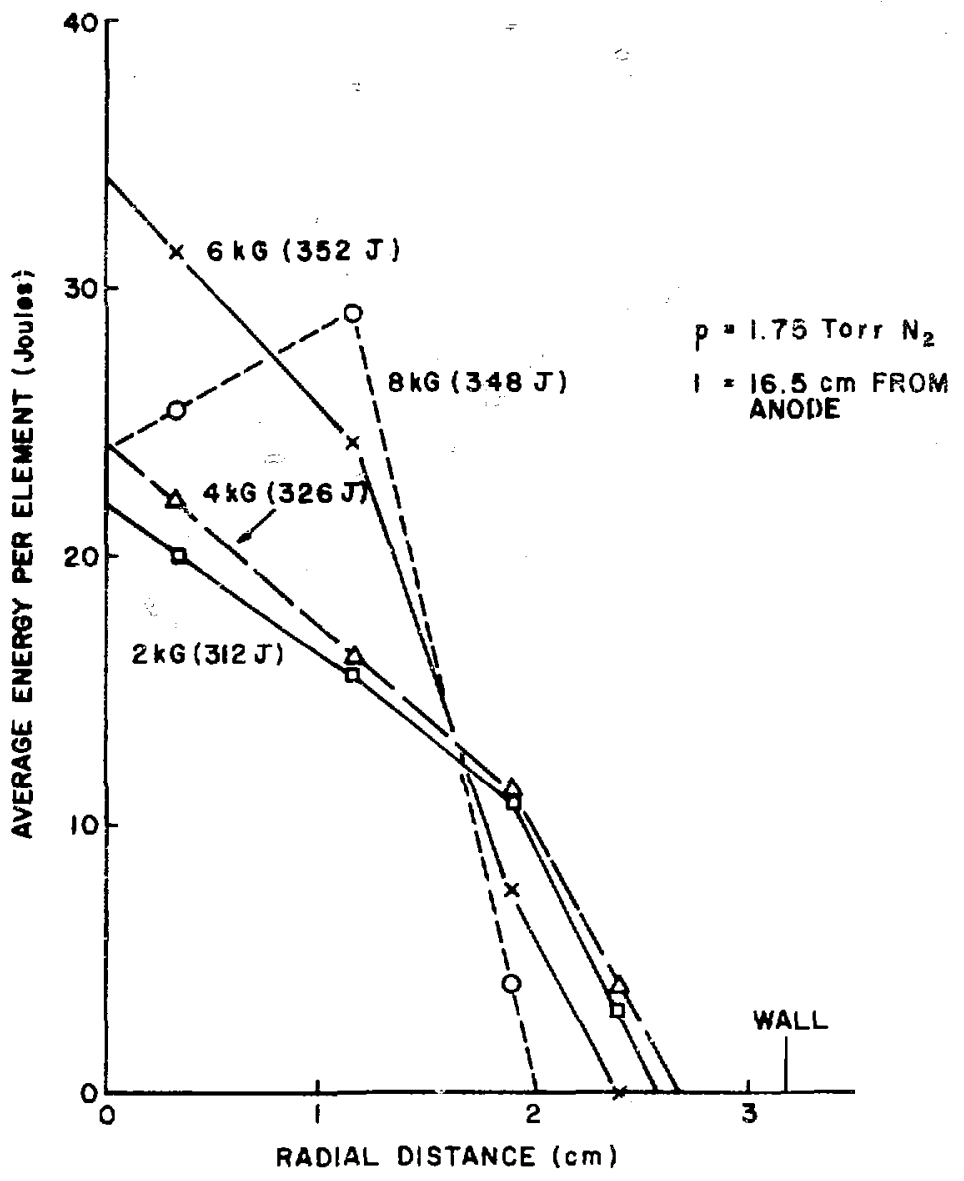

Figure 10. Radial electron-beam proriles and total transmitted energy as a function of optical magnetic field. 
of the beam, which is probably indicative of emission from the cathode. nt this magnetic ficld level, collective effects in the diode as well as scattering in the anpde are neariy eliminated. Since the energy did not increase significantly at $8 \mathrm{kG}$ and the profile was dipped in the center, 7 magnetic field of $6 \mathrm{kG}$ was chosen for, the rest of the experiments. 'phe eneryy stored in the capacitor bank for a $6 \mathrm{kG}$ field is $4.5 \mathrm{~kJ}$. Electron-Beam Steering

Once the operating magrietic field was selected, the calorimeter was asod to determine the optimum position of the turning coil. When the electrons are turned by magnetic field, they will experience an $\vec{q} \times \vec{B}$ curvature arift, 14 causing the electron beam to be deflected either to the top or bottom of the laser cell. In order to compensate for this irift, the turning coil must be tilted to obtain beam propagation along whe axis of the cell. The procedure used to obtained the correct position for the turning coil is essentially a trial and error process. Normally, the calorimeter is placed at a point beyond where the electrons enter the cell. In this particular cell, a distance of 41 cm from the anode was selected (see Fig. 8). The pressure in the cell should be approximately the same as that anticipated for laser operation. In our case, nitrogen was used in place of Eluorine since Eluorine would chemically $0 \times z=04$ the carbor caiorimeter. The coil $1:$ adjusted so that the beam

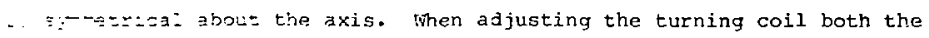
$\because \because \because \div \equiv+\because \because: Z:$ must be changed since they are coupled. Thus, correct

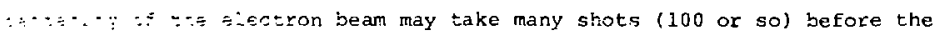
$\therefore \quad: \because . \ldots \therefore \because$ arrectly. When this position has been determined,

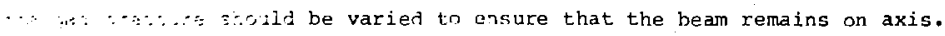

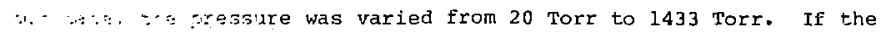




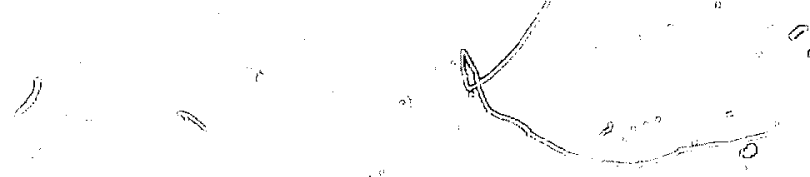

beam varies significantly, the coil should be ijusted slightly. When this had beer accomplished, the calorimeter was positioned near the end of the cell and bean "irofiles were checked fol a few pressures. After tire Einal setting, drift tube pressures, foll thickness, magnetig field

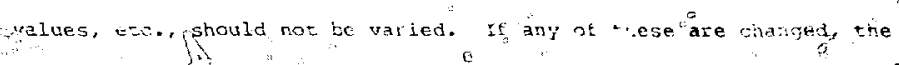
coil may have to be readjusteil.

\section{Electron-Beam Deposittion}

fifter determining the oftimun position for the turning wil, eieftrpn-beal

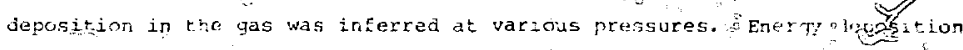
is required to determine beam propagation and to obtain intrinsic irser

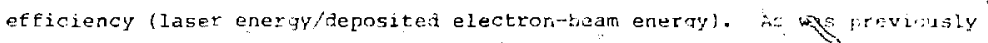
stated, nitrogen at the same density as a $\mathrm{k}_{2}, \mathrm{H}_{2}, \mathrm{O}_{2}$ mixture was ises for the deposition studies. Nitrogen was aseri at pressures of 173 , 354, 37, 716, 995, 1074, 1253 and 2432 Torr. These pressures correspond to 1ast mixtures $\left(\mathrm{F}_{2}: \mathrm{O}_{2}: \mathrm{H}_{2}=1: 0.3: 0.25\right)$, for partial pressures of Elwrinatef 100 ,

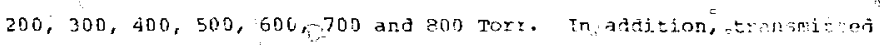
energy was obtainelu a nitrgigen pressure of $20 \mathrm{frr}$, whzch shourd given $A$ indication of the minimum anount of energy scattered to the wail, since at this pressure electron deposition in the gas should be negligiblo. " Transmitted energy was obtained at distances fron the anode of $41, \mathrm{~m}, \mathrm{~s}, \mathrm{n}$ and $126 \mathrm{~cm}$. The deposition was estimated by subtracting the amount of energy transmitsed at a given pressure from that transmittea at a pressure of 20 Torr. This gives an upper bound to the deposition since there is additional scatter higher pressures, which is shown in Fig. 11. This figure shows the electron-beam profilas at 716 Torr $\mathrm{N}_{2}$ and 1432 Torr $\mathrm{N}_{2}$ at three different axial fositions. A higher percentace of taansmitted energy was measured at a large radius for the higher pressure which 


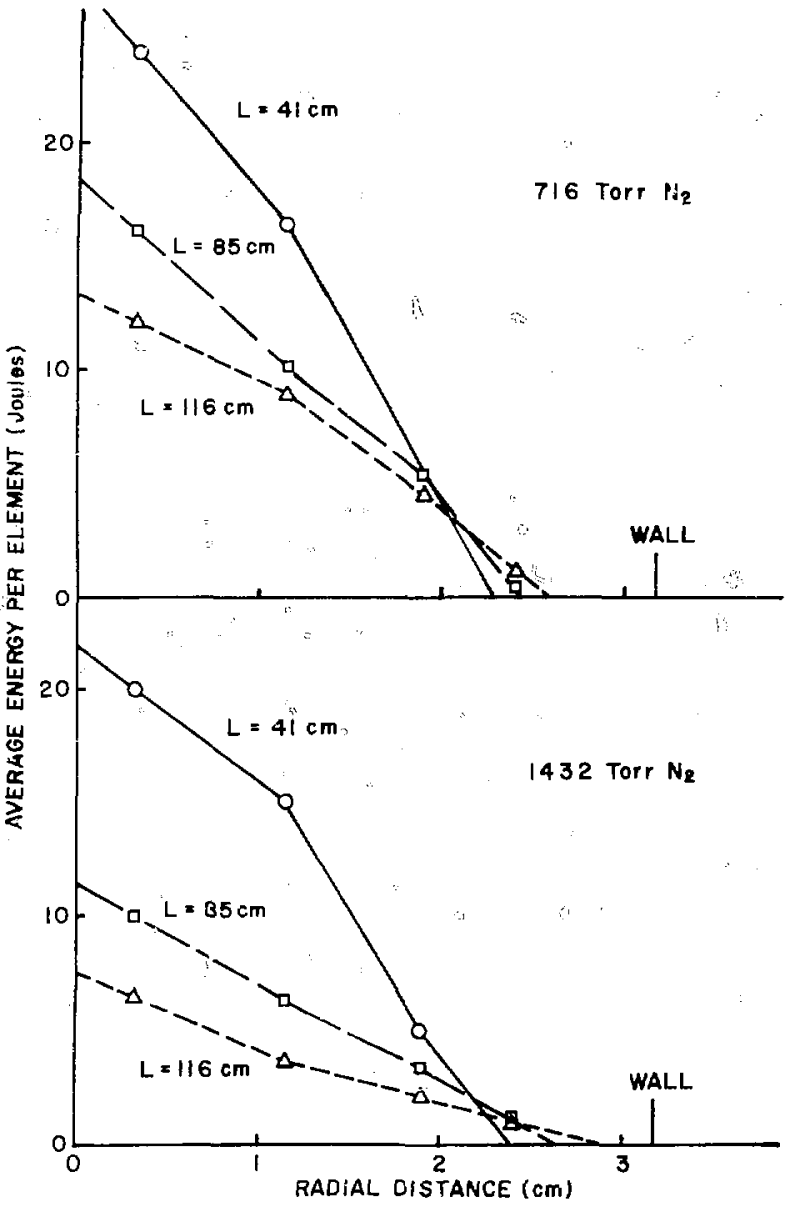

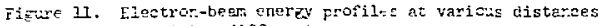
and st two different eas pressures. 
suggests scattering in the wall.

the total energy transmitted, at the varions pressures as a function of distance from the arode, is shown in Fig. 12. The lata for distarive: greater tlan $17 \mathrm{~cm}$ has been smaothed by using a lineat approximation to the data with pressure at a giver distance. The energy of the beam through the $0.076-m m-t h i c k$ Ti anode is approximately $400 \mathrm{~J}$. The dashed line at a distance of $17 \mathrm{~cm}$ represents the end iff the drift section. The measured loss through the $0.076 \mathrm{~mm}$ stainjass steel was about $8 \mathrm{t}$ of the incident energy. The second dusted line at $32 \mathrm{~cm}$ represents the point at which the electron bean exters the laser cell. The total energl deposited at a given pressure was determined by the difference between the transmitted energy at 20 Torr and transmitter enargy at tine desired pressures over the length of the cell $(124 \mathrm{~cm}-32 \mathrm{~cm})$. The deposited energy for each given $\mathrm{N}_{2}$ pressure is given in Table $\mathrm{I}$.

Table I. Deposited Energy as a Function of Pressure

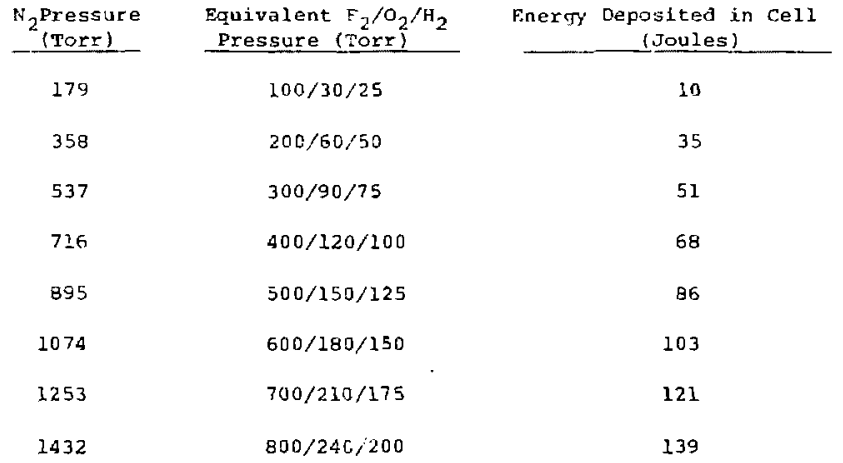

The $x$ aw data that was used to obtain the curves in Fig. 12 was also compared to Sandia's one-dimensjonal Monte Carlo deposition code. 15 A comparison of the measured bram energy lost to the calculations is shown 


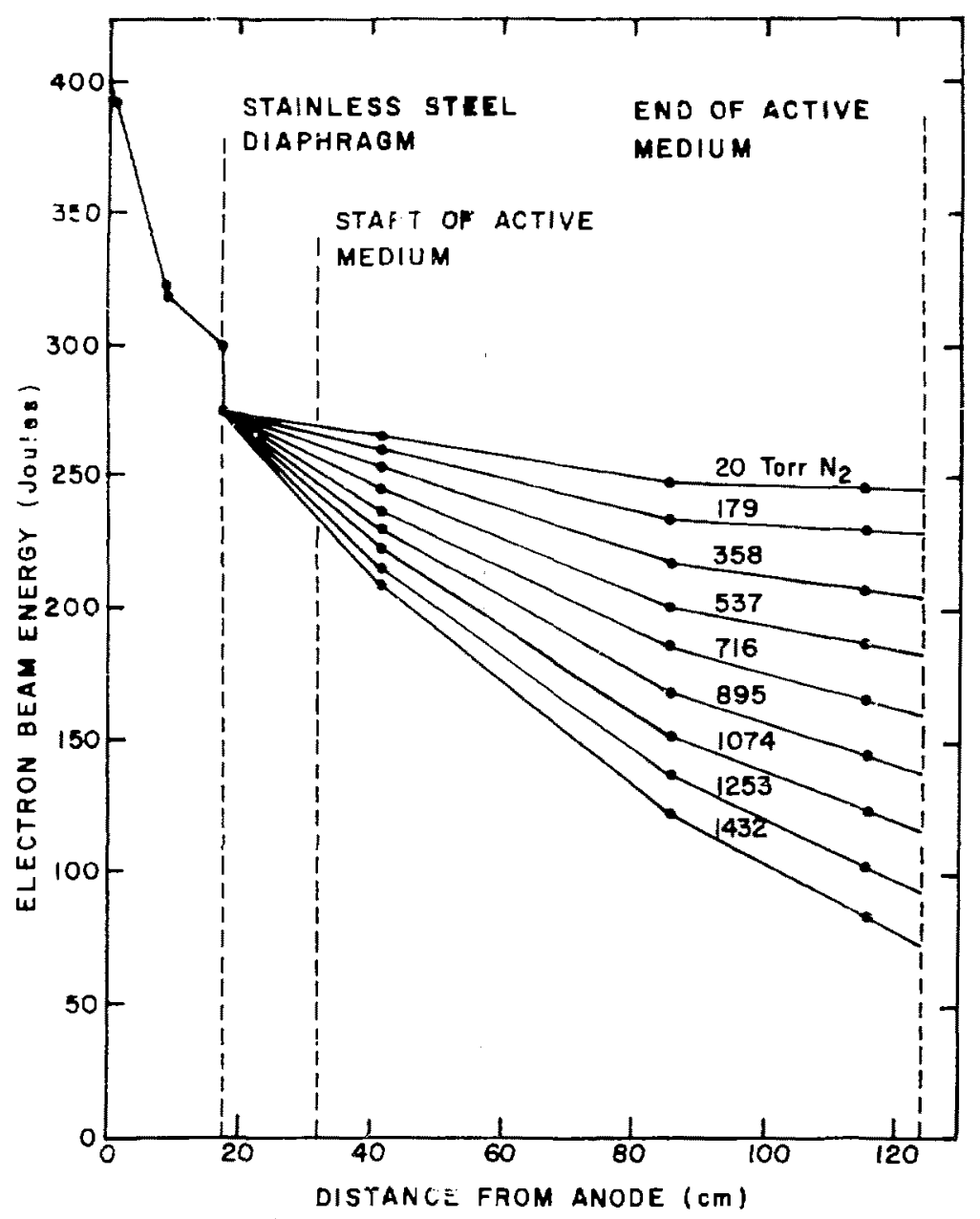

Hitur: 12. Elactron-begn enerey transmitted at various locations at differont $N_{2} \mathrm{~g} \leq \mathrm{s}$ pressures. 
in Fig. 13. The inztial beam energy (entering the laser chamber) was approximately $250 \mathrm{~J}$, and it was assumed that the energy of adh ilectron was $1.2 \mathrm{MeV}$. Figure 13 shows that the measured beam enf ry lost is larger than the calculations would fecict. ns previously mentioned, sime of this loss is due to scattering. The lower caiculated energy depusition could be due to the enterirg eiectron's energy actualiy being considerahly less than I. 2 MeV.

TYPICAL LASER RESUIETS

The laser system described here was first unaracterized as an HF osciliator using both Jas mixtures of $\mathrm{SE}_{6}-\mathrm{C}_{2} \mathrm{H}_{6}$ and $\mathrm{F}_{2}-\mathrm{O}_{2}-\mathrm{H}_{2}$. I6 :asel measurements includes erezgy, pulse width, and spectral identification as a function of gas pressure and concentration. Tis laser was then used as the oscillator in an oscillator-amplifier experiment to ietermine energy extraction of the phoenix $t$ amplifier. 17 necently the laser system was used as an intermediate amplifier in the saturated amolizier experiments using the Phoenix $\mathrm{l}$ final amplifier.la only one set of typical results will be given for inis system.

Figure 14 shows the energy and pulse width of the laser when operated as an oscillator. The optical cavity was of the stable configuration and consisted of a calciun-fluoride flat output coupler and a $10 \mathrm{~m}$ radius-of-curvature copper mirror. The cavity separation was $2.1 \mathrm{~m}$. The laser was fitted with sapphire $\left(\mathrm{Al}_{2} \mathrm{O}_{3}\right)$ Brewster angle windows for these measurements. The laser energy increases with increasing $\mathrm{F}_{2}$ pressure reaching a value of $90 \mathrm{~J}$ at an $\vec{F}_{2}$ pressure of 200 Torr. The pulse width uecreased from about 70 nsec at an $F_{2}$ pressure of 200 Tox to a pulse width of approximately 20 nsec at a pressure of 700 Torr $F_{2}$. The energy of the laser has been increased 


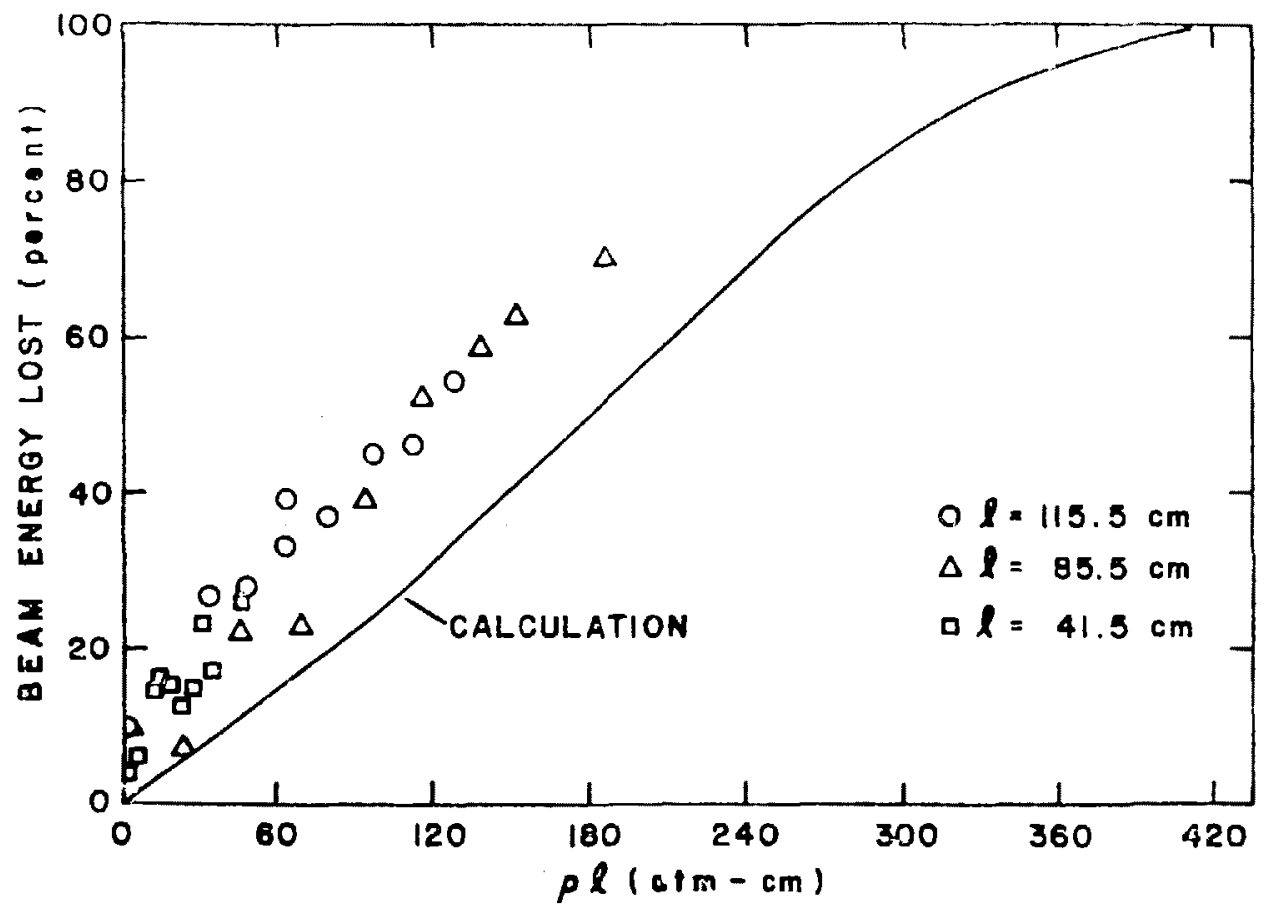

Figure 13. Meusured electron-bean enerizy lcin and calculated beam deposition as a function of density-leneth product. 


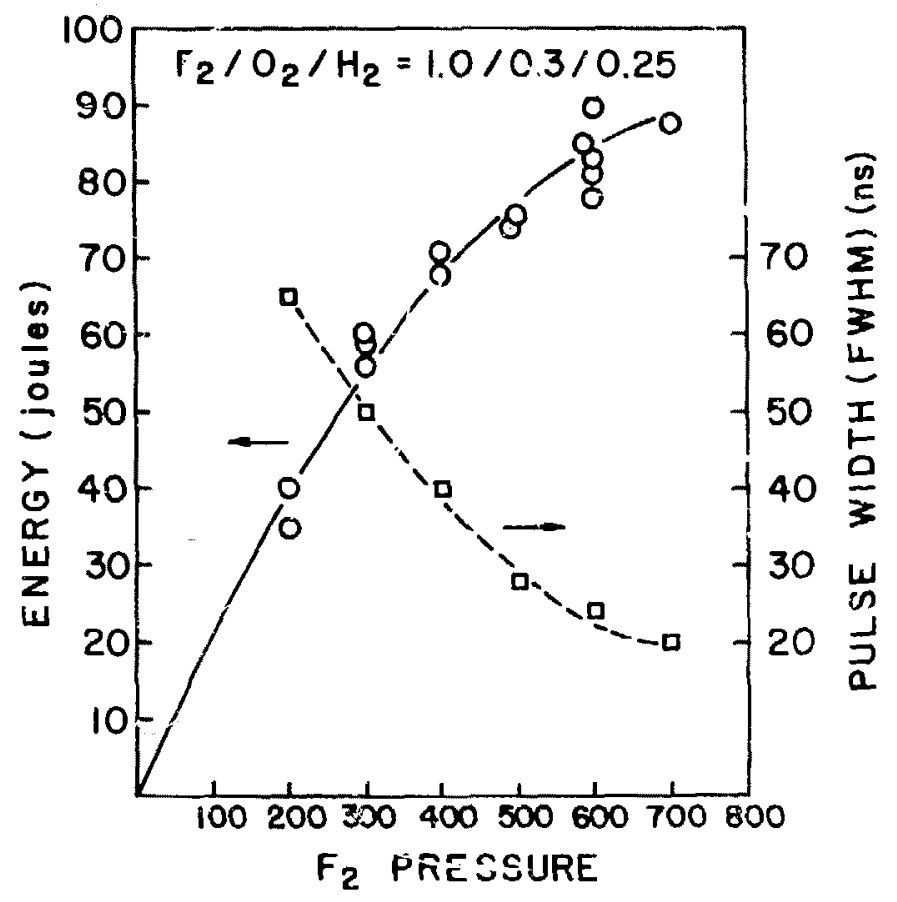

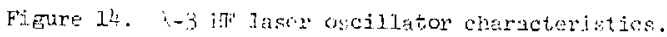


to apprczimately $I B O \mathrm{~J}$ by operating at hígher pressures. ACKNOWLEDGMENTS

The author acknowledges $\mathrm{E}$. I. Patterson for specifying the electron-beam machine and doing the initial check out on the machine,

R. A. Gerber and G. C. Tisone for their help in the deposition measurements, and J. M. Hoffman for the laser studies. 


\section{REFERENCES}

1. E. L. Patterson, R. A. Gerber and L. S. Blair, J. Appl. Phys. 45, $1822(1974)$.

2. E. L. Patterson and R. A. Gerber, IEES J. Quantum Flectron. QE:-11, $642(1975)$

3. R. A. Gerber and E. L. Patterson, J. Appl. Phys. 47, 3524 (1976).

4. J. M. hoffman, A. K. Hays, and G. C. Tisone, Appl. Phys. Lett. 28, $538(1976)$

5. J. K. Rice, A. K. Hays and J. R. Woodworth, hppl. Phys. Lett. 31, $31(1977)$.

6. J. R. Woodworth and J. K. Rice, J. Chem. Rhys. 69, 250n \{1973;.

7. Physics International Company, San Leandro, CA.

B. "Gas handling System for Sandia's HF Laser Facility," R. A. Kiein, Internal Menorandum, RS $4210 / 79 / 3$ (U), Sandia Laboratories, Albuquerque, iM, March 1979.

9. L. Pages, E. Borval, H. Joffro, and S. Klavenitis, Atomic Data (Academic Press, 1972) p. 18.

10. Ramo and Whinney, Fields and Waves in Modern Radio (Wiley sons, 1960) p. 236 .

11. Maxwell Laboratories, San Diego, CA, Specification No. 3713-62375, $50 \mathrm{~kJ}$, modile.

12. Segmentea Calorimeter Model 64l, United Scientific, Manzano Laboratories Division, Albuquerçue, Ni.

13. "Calorimeter Computer Description and Programming," J. C. Bagg, Internal Memorandum, RS 5210/125 (U), Sandia Laboratories, Albuguerque, WM, March 1979. 
14. Sutton and Shermon, Engineering Magnetohydrodynamics (McGraw-Hil1, 1965) p. 55 .

15. J. A. Halbleib, Sr, W. H. Vandevender, "Tiger: A One-Dimengional Multilayer Electron/Photon Monte Carlo Transport Code," SLA73-1026, Sandia Laboratories, Albuquerque, NM, March 1974.

16. J. M. Hoffman (private communication).

17. E. L. Patterson, J. M. Hoffman, and R. A. Gerber t to be published in J. Appl. Phys.).

18. E. L. Patterson, J. Ma Hoffman, and G. C. Tisone (to be published). 


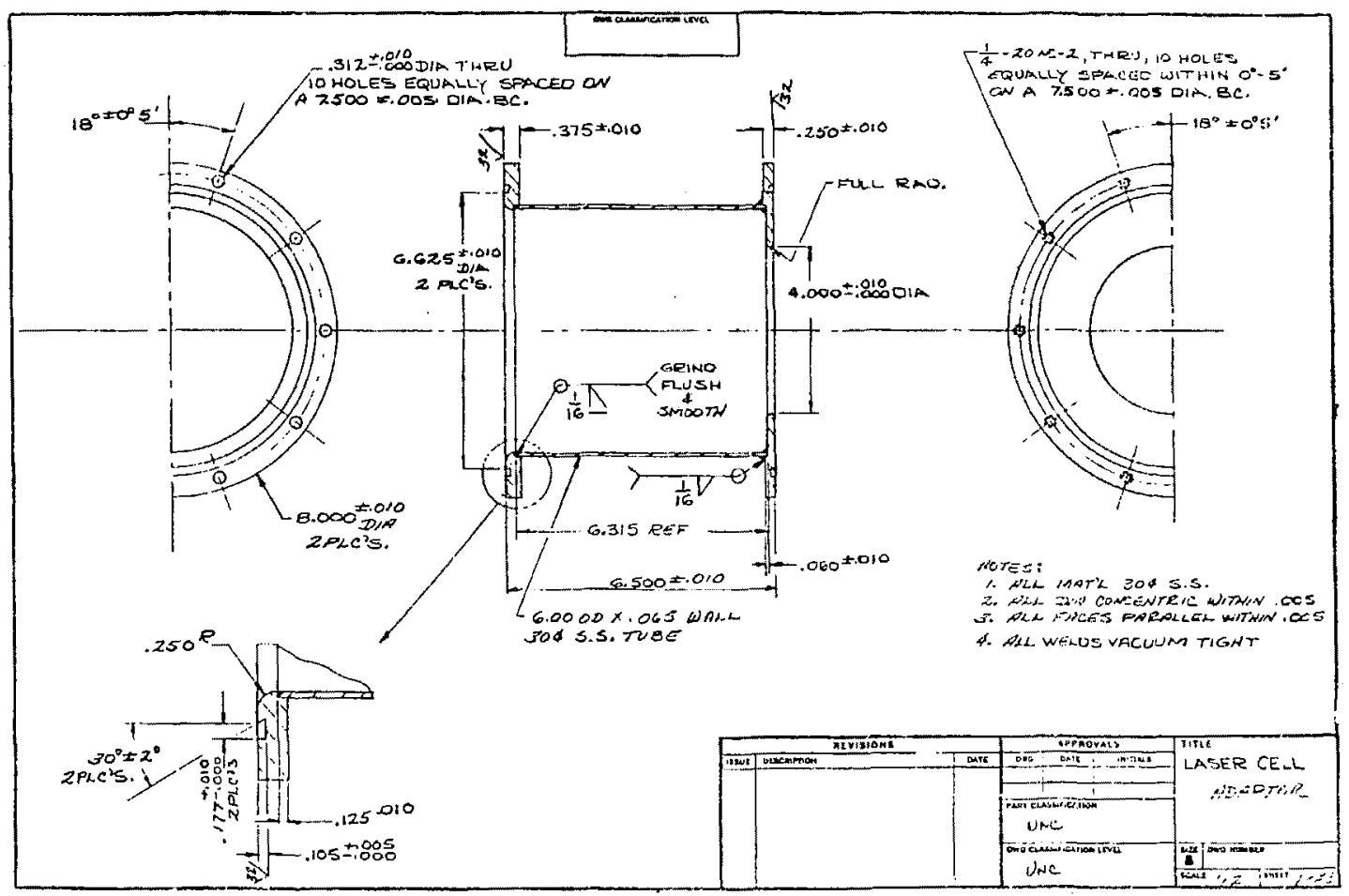

braing 1. celz stiopter 


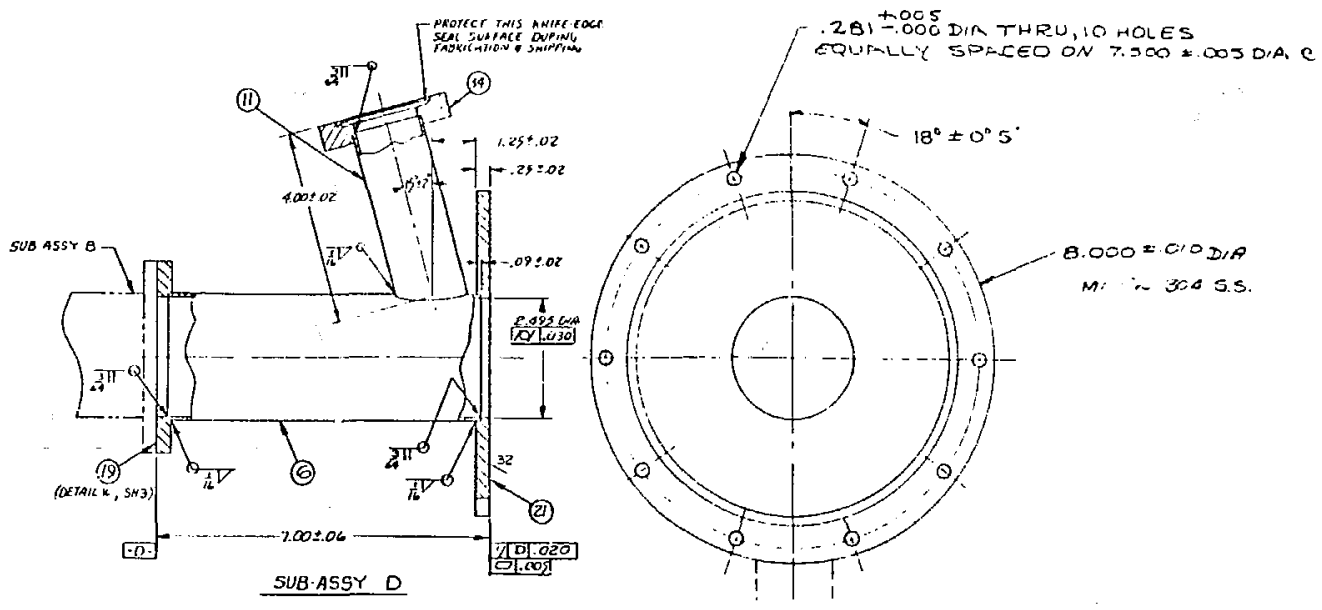

Drawing 2. Drift Section 


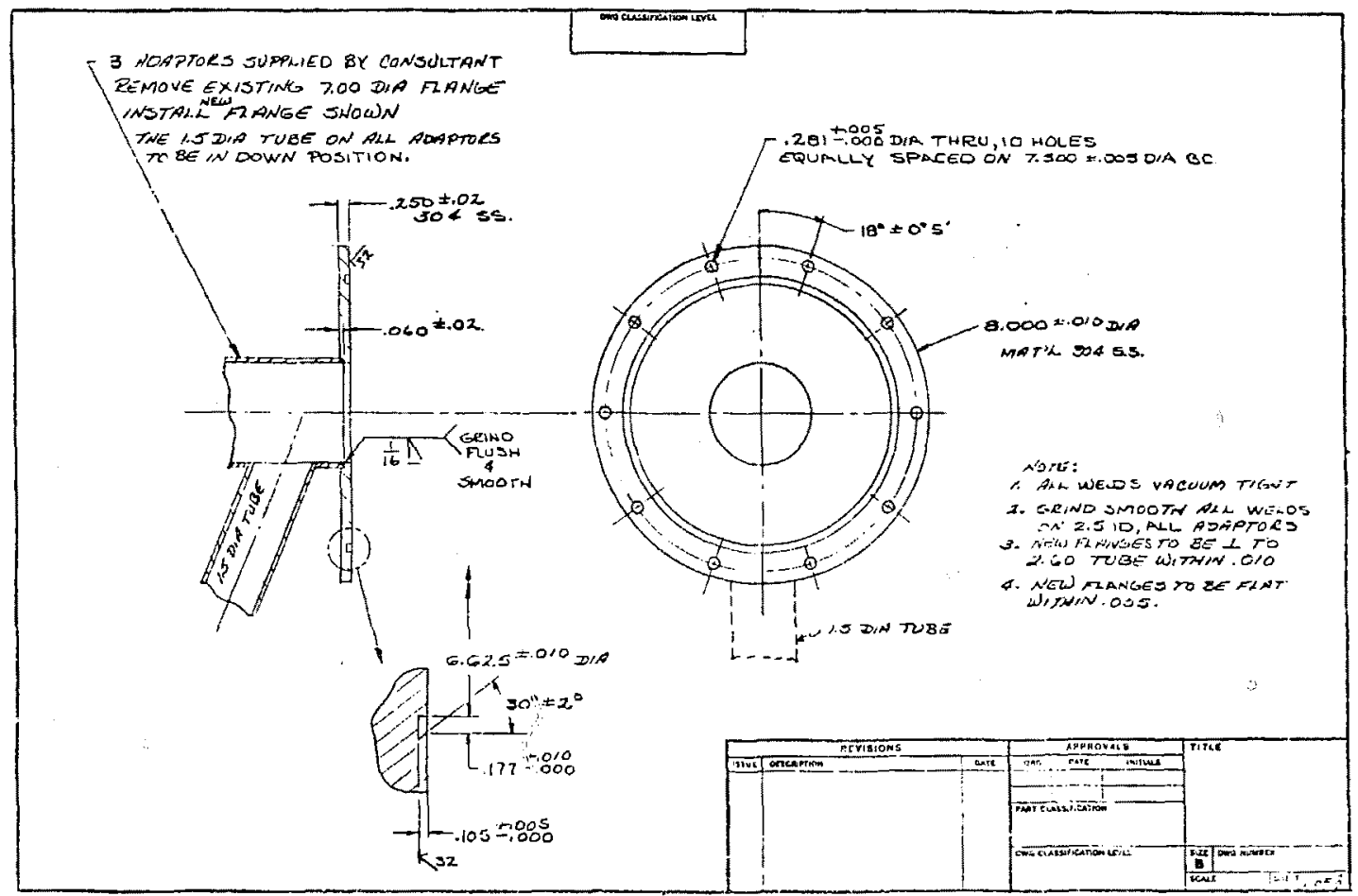

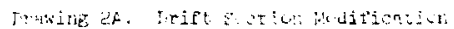




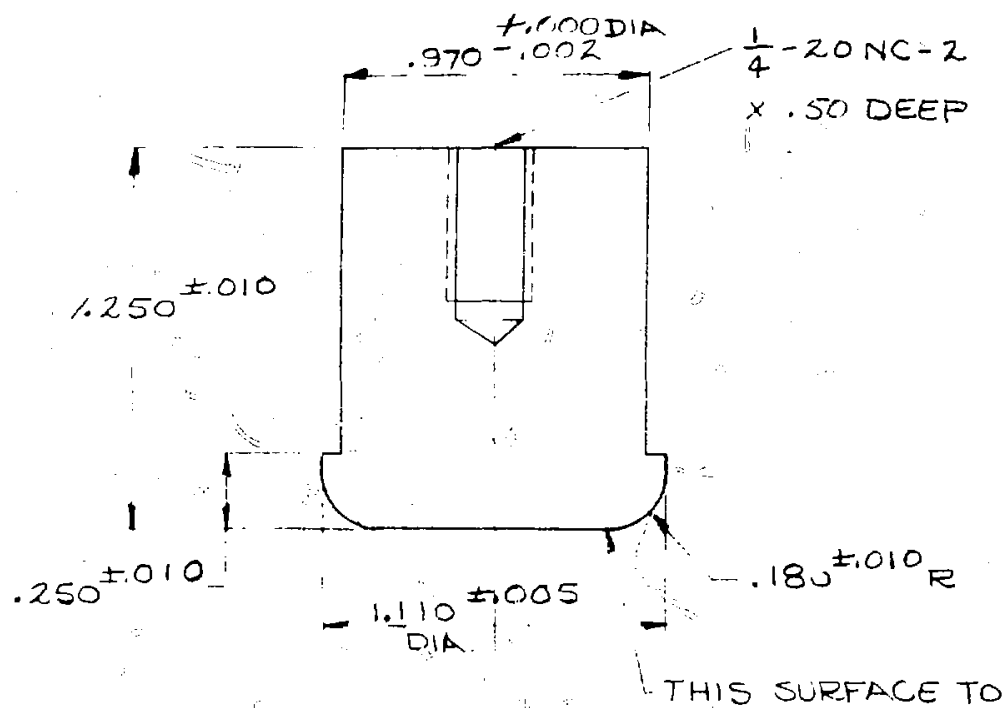

NATL:

ATS CARBON BE POLISHEO-NO NICKS OR MACHINE MARKS WILL BE ACCEPTABLE.

Drawing 3. Cathode Tip

40 


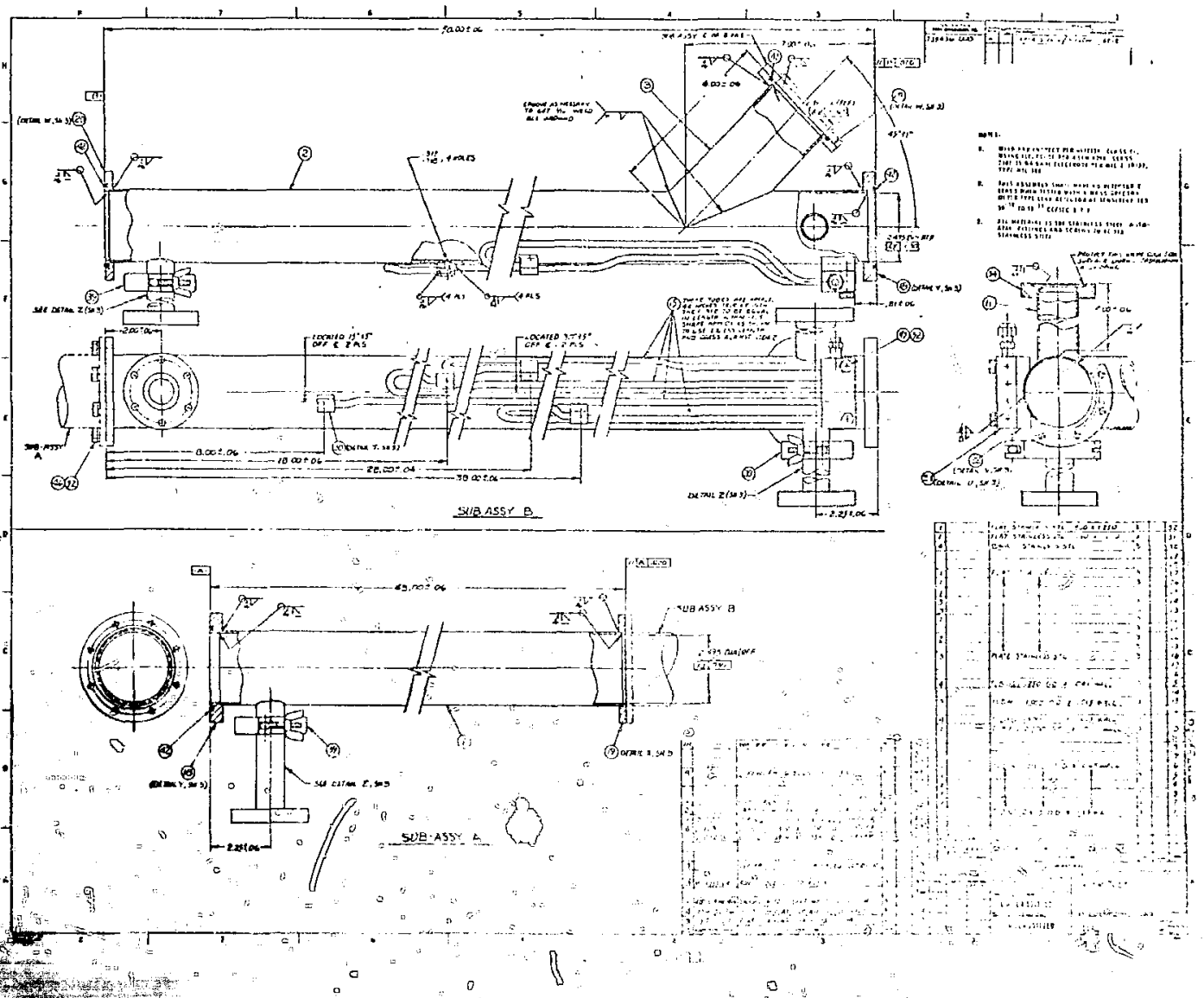




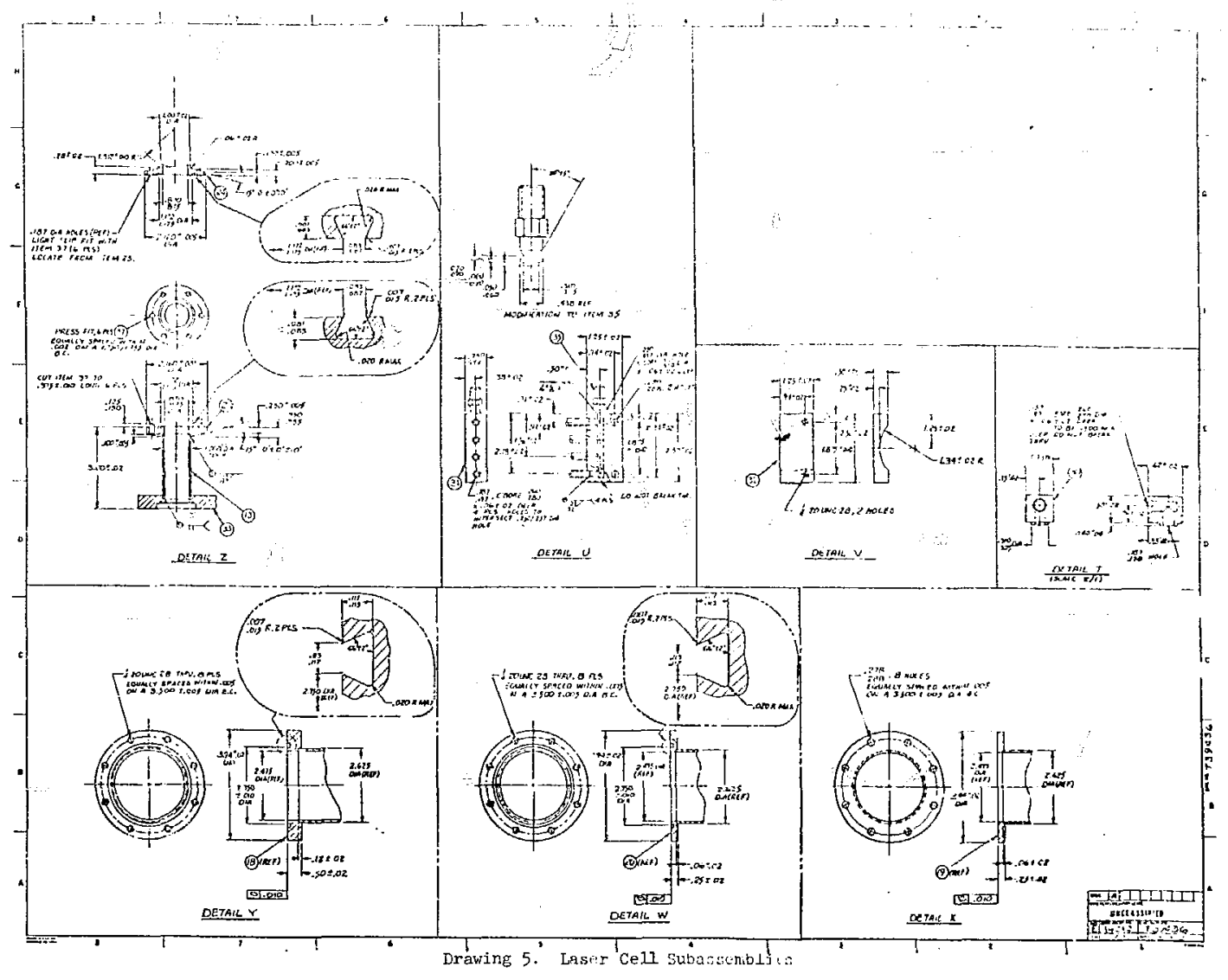




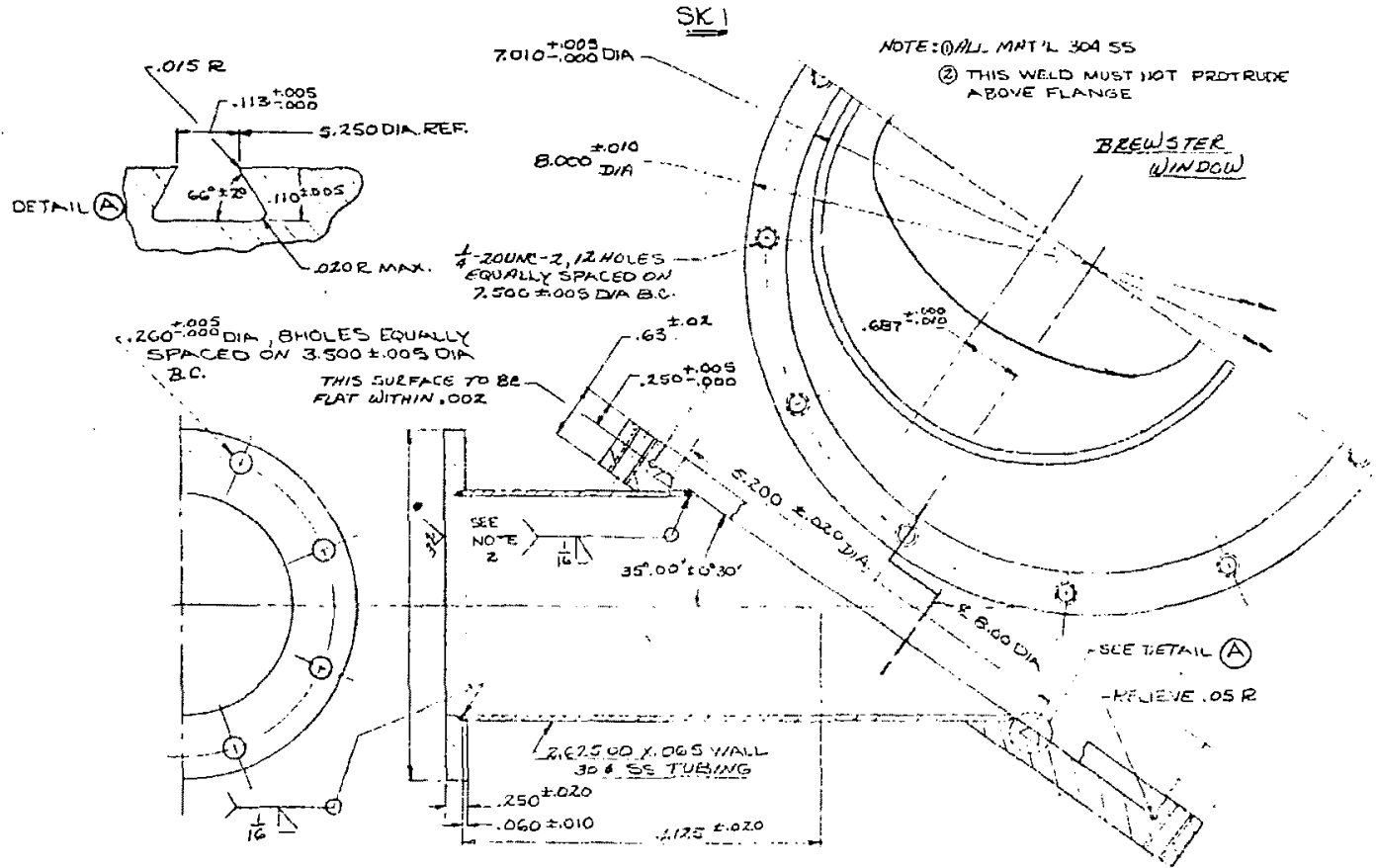

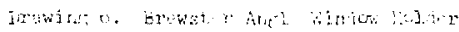




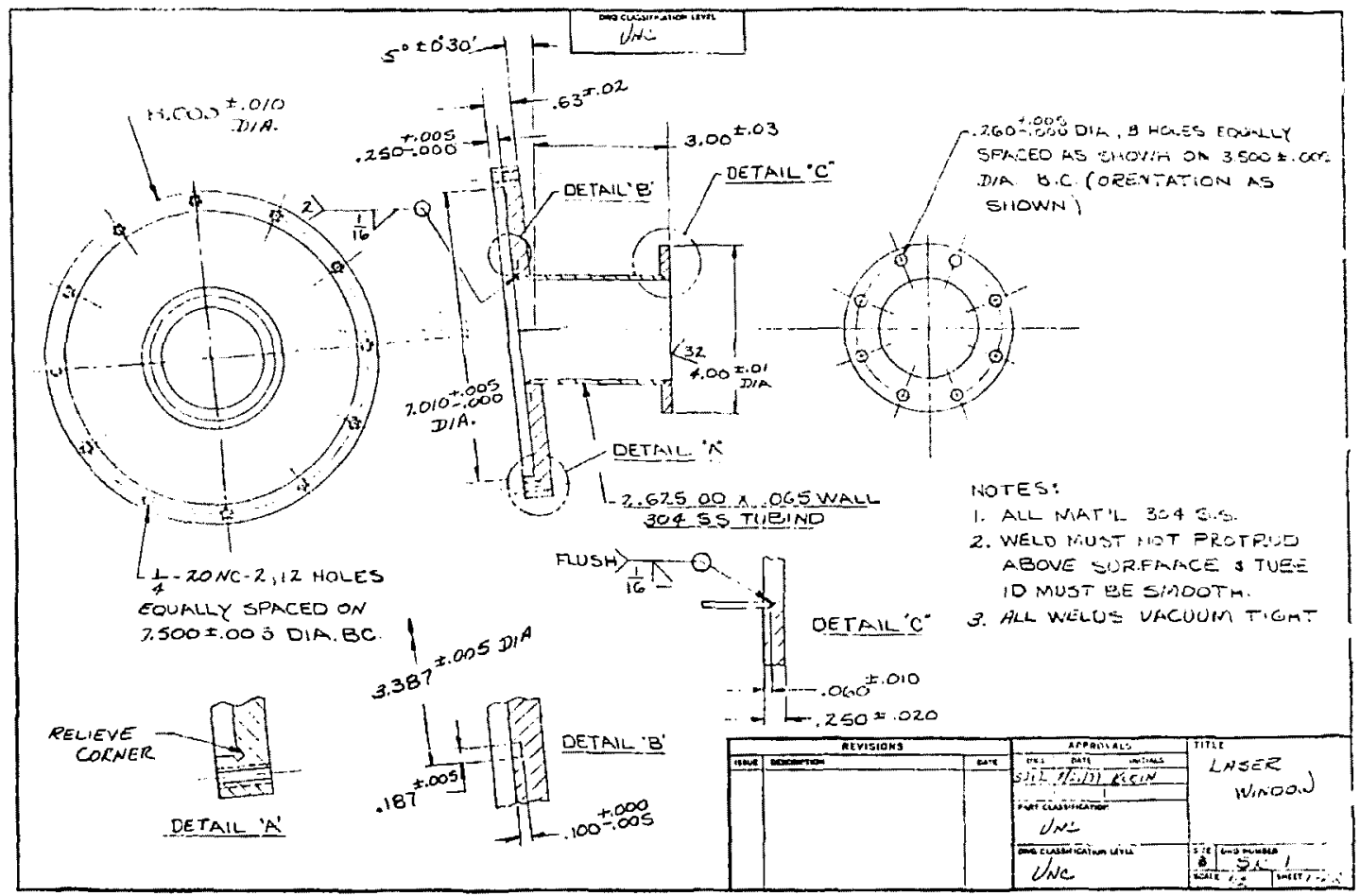

Drawing 7. $15^{\circ}$ Window llolder 


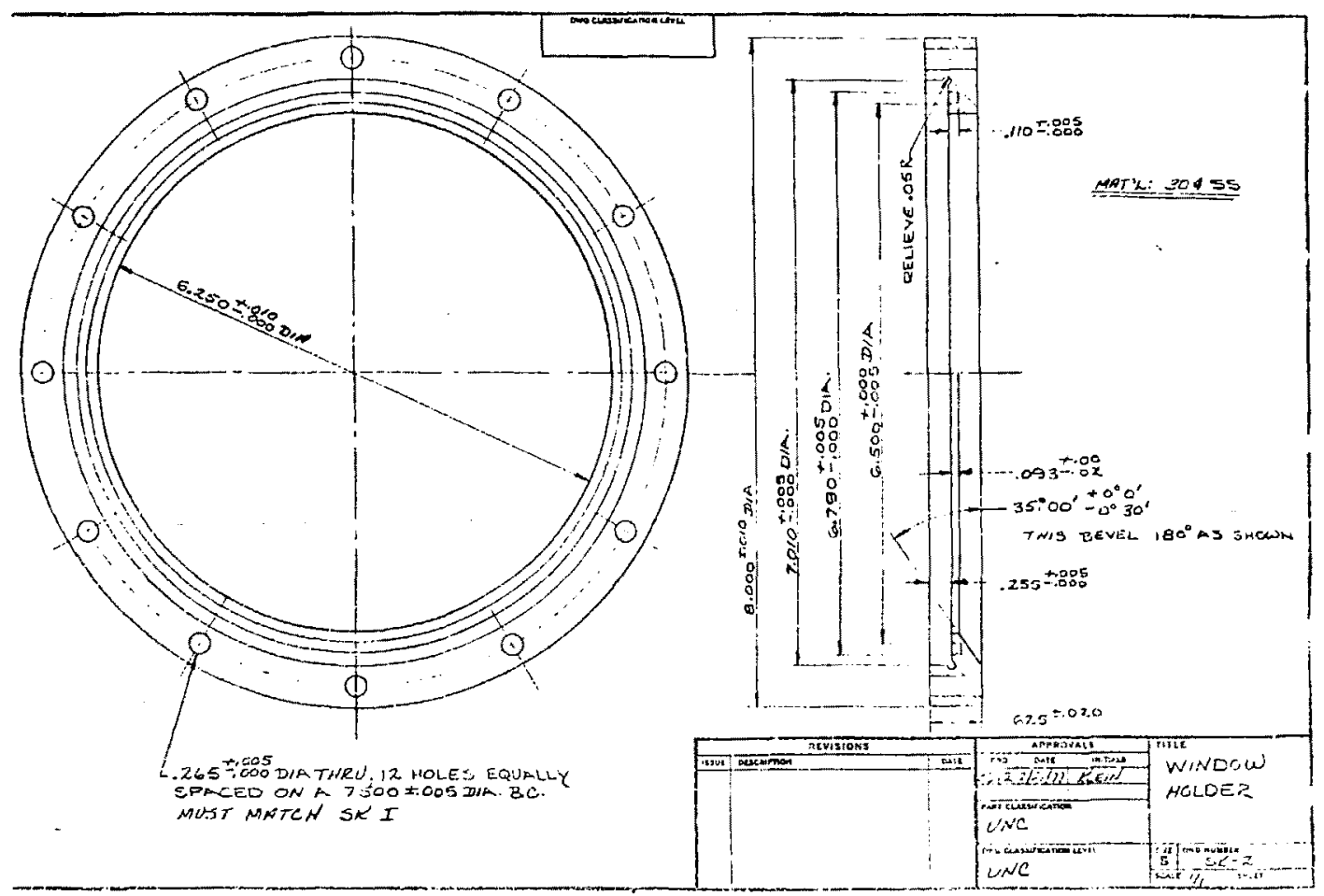

1 raving 8. Wiscris delup 